\title{
Contributions to the petrography, geochemistry and geochronology (U-Pb and Sm-Nd) of the Paleoproterozoic effusive rocks from Iricoumé Group, Amazonian Craton, Brazil
}

\author{
Contribuições para a petrografia, geoquímica e geocronologia \\ (U-Pb e Sm-Nd) das rochas efusivas Paleoproterozóicas do Grupo \\ Iricoumé, craton Amazônico, Brasil
}

\section{Suelen Nonata de Souza Marques ${ }^{1,3}$, Valmir da Silva Souza ${ }^{1,2 *}$, Elton Luiz Dantas ${ }^{2}$, Cristóvão da Silva Valério ${ }^{3}$, Rielva Solimairy Campelo do Nascimento ${ }^{1,4}$}

\begin{abstract}
RESUMO: O sul do escudo das Guianas no craton Amazônico hospeda volumoso registro de rochas efusivas paleoproterozóicas do Grupo Iricoumé em notável estado de preservação de texturas e estruturas. $\mathrm{O}$ conteúdo em $\mathrm{SiO}_{2}$ nessas rochas revela associação bimodal com rochas ácidas $\left(\mathrm{SiO}_{2}>67 \%\right)$ e intermediárias $\left(\mathrm{SiO}_{2}<57.7 \%\right)$. As rochas ácidas são riolitos a riodacitos com alto álcalis, $\mathrm{Rb}, \mathrm{Zr}$, $\mathrm{Nb}+\mathrm{Ta}, \mathrm{La}+\mathrm{Ce}$ e $10^{4} \mathrm{Ga} / \mathrm{Al}$, baixos $\mathrm{Fe}_{2} \mathrm{O}_{3 \text { ror }}, \mathrm{TiO}_{2}, \mathrm{CaO}, \mathrm{Sr}$ e Co, exibindo composição subalcalina, metaluminosa a peraluminosa, geoquímica compatível ao magmatismo do tipo A pós-colisional a intra-placa. As rochas intermediárias são basalto andesíticos a andesitos com alto $\mathrm{TiO}_{2}, \mathrm{Al}_{2} \mathrm{O}_{3}, \mathrm{Fe}_{2} \mathrm{O}_{3 \text { total }}, \mathrm{MgO}, \mathrm{CaO}$, Sr e Co, baixo $\mathrm{SiO}_{2}, \mathrm{~K}_{2} \mathrm{O}, \mathrm{Rb}, \mathrm{Zr}, \mathrm{Nb}+\mathrm{Ta}$, La $+\mathrm{Ce}$, composição subalcalina, metaluminosa e geoquímica de basalto intra-placa. A idade $\mathrm{U}-\mathrm{Pb}$ de cristalização das rochas ácidas, obtida em zircão por LA-MC-ICPMS é de $1.882 \pm 11 \mathrm{Ma}$. Os dados isotópicos $\mathrm{Sm}$-Nd obtidos para os diferentes tipos de rochas revelaram idade modelo $\mathrm{Nd} \mathrm{T}_{\mathrm{DM}}$ entre 2.59 e $2.16 \mathrm{Ga}$ e valores de $\varepsilon_{\mathrm{Nd}}(\mathrm{t})$ entre -5.78 e 0.03 , indicando evoluçáo magmática envolvendo retrabalhamento de crosta continental paleoproterozóica (crosta transamazônica) no período Rhyaciano-Sideriano, com algum grau de mistura com magmas derivados do manto ou contaminação por crosta arquena. As informaçôes petrográficas, geoquímicas e geocronológicas neste trabalho sugerem um ambiente pós-colisional a intra-placa para o vulcanismo Iricoumé, envolvendo elevação da crosta inferior e geração de magmas basálticos em um regime extensional.
\end{abstract}

PALAVRAS-CHAVE: cráton Amazônico; escudo das Guianas; Grupo Iricoumé; vulcanismo bimodal; Paleoproterozóico.

\begin{abstract}
The southernmost region of the Guyana shield, Amazonian craton, hosts large record of Paleoproterozoic effusive rocks of the Iricoumé Group. They present remarkably well-preserved igneous textures and structures. The $\mathrm{SiO}_{2}$ contents reveal a bimodal association marked by a compositional gap between acid $\left(\mathrm{SiO}_{2}>67 \mathrm{wt} \%\right)$ and intermediate $\left(\mathrm{SiO}_{2}<57.7 \mathrm{wt} \%\right)$ rocks. The acid effusive rocks are rhyolites to rhyodacites with high $\mathrm{SiO}_{2}$, alkali, $\mathrm{Rb}, \mathrm{Zr}, \mathrm{Nb}+\mathrm{Ta}, \mathrm{La}+\mathrm{Ce}$ and $104 \mathrm{Gal}$ Al content and low $\mathrm{Fe}_{2} \mathrm{O}_{3}, \mathrm{TiO}_{2}, \mathrm{CaO}$, Sr and Co content. They exhibit subalkaline, metaluminous-to-peraluminous compositions, and geochemically compatible to A-type magmatism emplaced in post-collisional to within-plate tectonic settings. The intermediate rocks are andesitic/basalt to andesite relatively high contents of $\mathrm{TiO}_{2}, \mathrm{Al}_{2} \mathrm{O}_{3}, \mathrm{Fe}_{2} \mathrm{O}_{3 \text { totaP }} \mathrm{MgO}, \mathrm{CaO}$, Sr and Co; low $\mathrm{SiO}_{2}, \mathrm{~K}_{2} \mathrm{O}, \mathrm{Rb}, \mathrm{Zr}, \mathrm{Nb}+\mathrm{Ta}, \mathrm{La}+\mathrm{Ce}$. They have subalkaline and metaluminous geochemical composition and plot on within-plate basalt field. The acid rocks crystallized at $1882 \pm 11 \mathrm{Ma}$ in U-Pb analyses for LA-MC-ICPMS zircon data. The Sm-Nd isotopic data on all rocks reveal a Nd TDM model ages between 2.59 and $2.16 \mathrm{Ga}$ and $\varepsilon_{N d}(t)$ values between -5.78 and 0.03 , indicate that the magmatic evolution was related to the reworking of older Paleoproterozoic at the Rhyacian-Siderian period, continental crust (Transamazonian crust-forming event) with some mixing with a limited amount mantle-derived magmas or with contamination by Archean crust. The petrographic, geochemical and geochronological data presented in this paper suggest a within-plate to post-collisional tectonic setting for the Iricoumé volcanism, involving lower crust uplift and generation of basalt magma in an extensional regime.
\end{abstract}

KEYWORDS: Amazonian craton; Guyana shield; Iricoumé Group; bimodal volcanism; Paleoproterozoic.

\footnotetext{
${ }^{1}$ Program for Post-Graduation in Geosciences, Universidade Federal do Amazonas - UFAM, Manaus (AM), Brazil. E-mail: suelen-marques@hotmail.com ${ }^{2}$ Geosciences Institute, Universidade de Brasília - UNB, Brasília (DF), Brazil. E-mail: vsouza@unb.br, elton@unb.br ${ }^{3}$ Geosciences Institute, Universidade Federal de Roraima - UFRR, Boa Vista (RR), Brazil. E-mail: cristovao@igeo.ufrrbr ${ }^{4}$ Geosciences Departament, Universidade Federal do Amazonas - UFAM, Manaus (AM), Brazil. E-mail: rielva@ufam.edu.br *Corresponding author

Manuscrito ID 29985. Recebido em: 11/06/2013. Aprovado em: 08/01/2014
} 


\section{INTRODUCTION}

The central part of the Amazonian craton hosts extensive records of Paleoproterozoic volcano-plutonic magmatic associations distributed on NW-SE trend (Fig. 1A). They are included in regional units known as Iricoumé-Mapuera within the Guyana shield and Iriri-Maloquinha, within the Guaporé shield, comprising the voluminous Uatumá magmatic event (Tassinari \& Macambira 1999; Tassinari et al. 2000; Santos et al. 2000; Pinho et al. 2004; CPRM 2006 \& 2008; Fernandes et al. 2006; Ferron et al. 2006 \& 2010; Valério et al. 2009 \& 2012; Juliani \& Fernandes 2010; Rocha et al. 2012; Klein et al. 2012).

The Iricoumé-Mapuera magmatic association consists of effusive and pyroclastic rock units of acid to intermediate composition forming the Iricoumé Group, which is intruded by geochemically similar alkali-rich granites known as the Mapuera Intrusive Suite. The northeastern region of Amazonas state (Fig. 1) displays excellent exposures of the Iricoumé-Mapuera association, which, during the last decade, have become the object of scientific research focusing on the petrographic, geochemical and geochronological characteristics (Valério 2006, 2011; Ferron 2006; Pierosan 2009; Marques 2011; Costa 2010). These studies have demonstrated that the Iricoumé-Mapuera association is formed by A-type magmatism with metaluminous to weakly peraluminous compositions, with geochemical affinity towards within-plate to post-collisional tectonic setting. The available geochronological data, mainly those obtained from the zircon ${ }^{207} \mathrm{~Pb} /{ }^{206} \mathrm{~Pb}$ evaporation method, indicate crystallization ages between 1879 and 1897 Ma. However, Nd-Sr-Hf isotopic data are still limited or nonexistent. Tab. 1 summarizes the isotopic information available for the Iricoumé volcanic rocks in the southern Guyana shield.

In this study, we present new data on the petrography, whole-rock geochemistry and geochronology ( $\mathrm{U}-\mathrm{Pb}$ and $\mathrm{Sm}-\mathrm{Nd}$ ) of effusive rocks from the Iricoumé Group in the northeastern region of Amazonas state, and compare them with the information available in the literature. Their petrogenesis and the geodynamic evolution associated with the Paleoproterozoic volcanic processes in the Amazonian craton.

\section{ANALYTICAL METHODS}

The petrographic investigations were performed at the microscopy laboratory of the Department of Geosciences, Universidade Federal do Amazonas (DEGEO-UFAM). The samples were chosen and prepared for geochemistry and isotopic $(\mathrm{Sm}-\mathrm{Nd})$ analyses at the laboratories of the DEGEO-UFAM, using conventional crushing in a jaw mill and in agate pot. Geochemical analyses were undertaken at the ACME Analytical Laboratories, Vancouver, Canada. The samples were analyzed for major elements $\left(\mathrm{SiO}_{2}, \mathrm{TiO}_{2}\right.$, $\mathrm{Al}_{2} \mathrm{O}_{3}, \mathrm{Fe}_{2} \mathrm{O}_{3 \text { tot }}, \mathrm{MnO}, \mathrm{MgO}, \mathrm{CaO}, \mathrm{Na}_{2} \mathrm{O}, \mathrm{K}_{2} \mathrm{O}$ and $\mathrm{P}_{2} \mathrm{O}_{5}$ ) by Inductively Coupled Plasma-Emission Spectrometry and for trace and rare-earth elements by Inductively Coupled Plasma-Mass Spectrometry (ICPMS).

The isotopic analyses $(\mathrm{U}-\mathrm{Pb}$ and $\mathrm{Sm}-\mathrm{Nd})$ were carried out at the isotope geology laboratories of the Universidade de Brasília, by applying the analytical procedures described below:

- U-Pb analyses by LA-MC-ICPMS followed the analytical procedure described by Bühn et al. (2009). Zircon concentrates were extracted using conventional gravimetric and magnetic separation techniques. The zircon grains were selected under a binocular microscope to obtain fractions of similar size, shape and colour. For in situ U-Pb isotopic analysis, hand-picked zircon grains were mounted in epoxy mounts and polished to obtain a smooth surface. The samples were mounted in an in-house, specially designed laser cell and loaded into a New Wave UP213 Nd:YAG laser $(\lambda=213 \mathrm{~nm})$, linked to a Thermo Finnigan Neptune Multi-collector ICPMS. Helium was used as the carrier gas and mixed with argon before entering the ICP. The laser was run at a frequency of $10 \mathrm{~Hz}$ and energy of $-100 \mathrm{~mJ} / \mathrm{cm}^{2}$ with a spot size of $30 \mu \mathrm{m}$ for U-Pb dating and $40 \mu \mathrm{m}$ for $\mathrm{Hf}$ isotopic analyses. Plotting of U-Pb data and age calculations were performed using ISOPLOT 3.0 (Ludwig 2003), and errors for isotopic ratios are presented at $1 \sigma$ level.

- Sm-Nd isotopic analyses followed the method described by Gioia \& Pimentel (2000). Whole-rock powders (ca. $50 \mathrm{mg}$ ) were mixed with a ${ }^{149} \mathrm{Sm}-{ }^{150} \mathrm{Nd}$ spike solution and dissolved in Savillex capsules. Sm and Nd extraction of whole-rock samples followed conventional cation exchange techniques, using Teflon columns containing LN-Spec resin ([di-(2-ethylhexyl) phosphoric acid (HDEHP) supported on PTFE powder). Sm and $\mathrm{Nd}$ samples were loaded on re-evaporation filaments of double filament assemblies and the isotopic measurements were carried out on a multi-collector Finnigan MAT 262 mass spectrometer in static mode. Uncertainties for $\mathrm{Sm} / \mathrm{Nd}$ and ${ }^{143} \mathrm{Nd} /{ }^{144} \mathrm{Nd}$ ratios are better than $\pm 0,2 \%(2 \sigma)$ and $\pm 0.003 \%(2 \sigma)$, respectively, based on repeated analyses of international rock standards BHVO-1 and BCR-1. ${ }^{143} \mathrm{Nd} /{ }^{144} \mathrm{Nd}$ ratios were normalized to ${ }^{146} \mathrm{Nd} /{ }^{144} \mathrm{Nd}$ of 0.7219 and the decay constant $(\lambda)$ used was $6.54 \times 10^{-12}$.

\section{GEOLOGICAL SETTING}

The southernmost of the Guyana shield includes the boundary region between the Paleoproterozoic basement and 


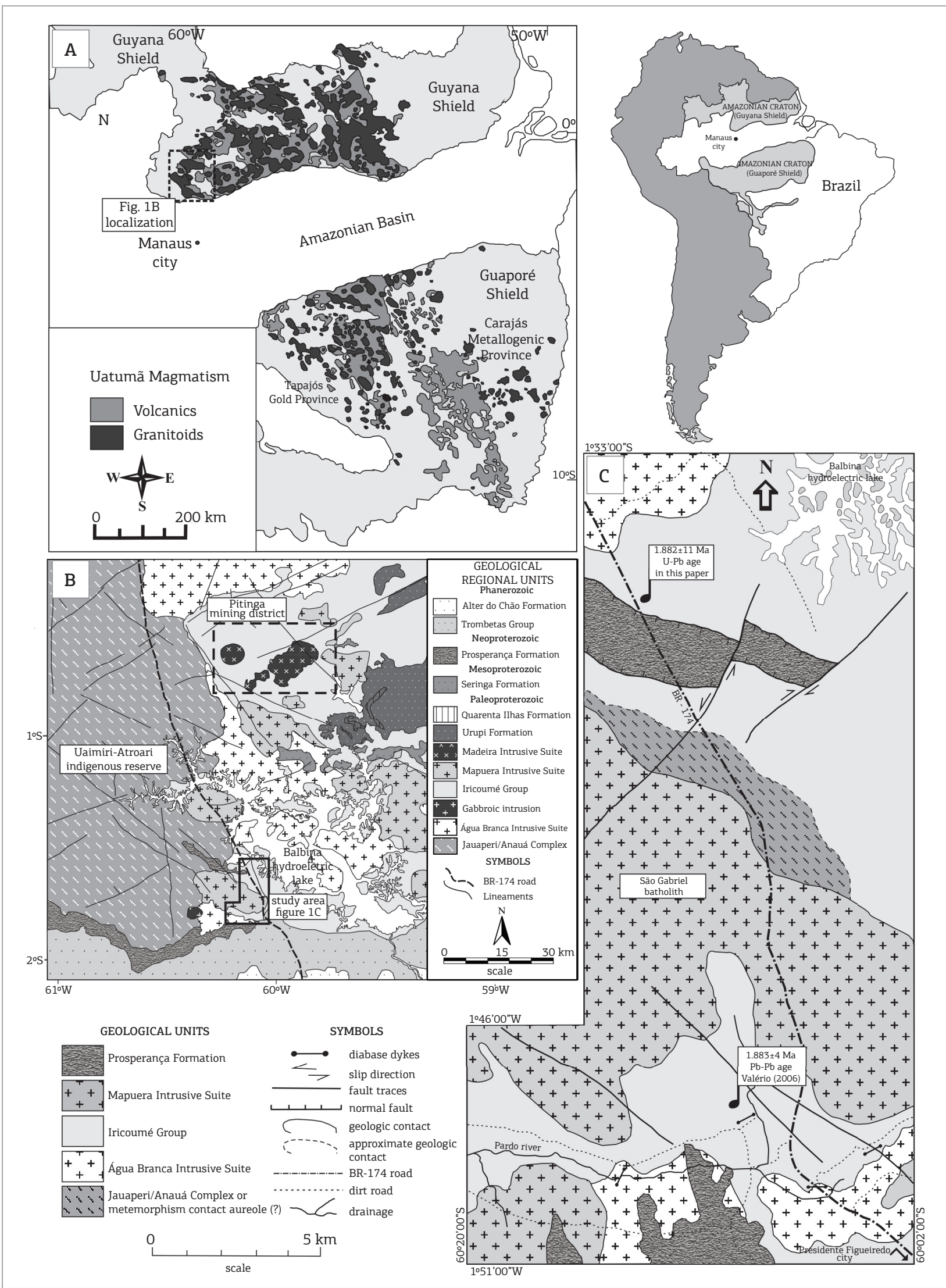

Figure 1. (A) Distribution of the Uatumã magmatic event in the Brazilian portion of the Amazonian craton and location of the study area (modified from Pierosan et al. 2011a). (B) Regional geological map and localization of the study area (modified from Valério et al. 2012). (C) Geological map of the study area (modified from Marques 2011). 
the Silurian-Devonian to Cretaceous sedimentary cover of the northern edge of the Amazon Basin (Fig. 1). The Paleoproterozoic basement includes gneisses, migmatites, meta-granites, amphibolites and charnockites comprising the so-called Jauaperi/Anauá Complex. The geochronological data on the basement rocks are still inconclusive and vary from 2.02 to $1.86 \mathrm{Ga}$ (Santos et al. 2002; Reis et al. 2003; CPRM 2006; Almeida 2006). In the study area, the nature of these metamorphic rocks is controversial. Some geologists believe that they represent products of contact metamorphism produced by Paleoproterozoic Mapuera Intrusive Suite, represented by the A-type São Gabriel batholith, but others suggest that they are simply the exposure of Paleoproterozoic basement rocks (Fig. 1C).

Four Paleoproterozoic (1900 - $1782 \mathrm{Ma}$ ) involving I- and A-type magmatic events are recognized in the region (Fig. 1B) as follows: (1) the Água Branca Intrusive Suite (1900 $1890 \mathrm{Ma}$ ) is characterized by an expanded granite series that varies from predominantly porphyritic to seriate-textured monzogranites and granodiorites to diorites. These rocks are metaluminous to peraluminous, calc-alkaline with high-K I-type geochemical signature (Araújo Neto \& Moreira 1976; Almeida 2006; CPRM 2006; Almeida \& Macambira 2007; Valério 2006, 2011; Valério et al. 2006, 2009, 2012); (2) the Iricoumé Group (1897 - $1881 \mathrm{Ma}$ ) comprises effusive rocks and pyroclastic flow associations. These rocks are metaluminous to weakly peraluminous, subalkaline with high-K and A-type affinity; (3) the Mapuera Intrusive Suite (1889 - 1871 $\mathrm{Ma}$ ) is represented by monzogranite, syenogranite and alkalifeldspar granite stocks. These rocks are weakly peraluminous, subalkaline with high-K, and have geochemical characteristics similar to A-type granites. Due to the geochemical and geochronological similarities between felsic volcanic rocks of the Iricoumé Group and granitic rocks of the Mapuera Suite, these rocks have been interpreted as a coeval volcano-plutonic association and inserted as part of the regional units known as the Uatumã Supergroup (Oliveira et al. 1975; Araújo
Neto \& Moreira 1976; Veiga et al. 1979; Schobbenhaus et al. 1994; Costi et al. 2000; CPRM 2006; Valério et al. 2009, 2012; Ferron et al. 2006, 2010; Pierosan et al. 2011a, 2011b; Berreto et al. 2013); and (4) the Madeira Intrusive Suite (1834$1782 \mathrm{Ma}$ ) occurs in the Pitinga Sn-mine area and is composed by biotite-syenogranite, alkali-feldspar rapakivi, hipersolvus and albite granite stocks bearing cryolite-zircon-cassiterite-pyroclore-columbite-xenotime mineralization. These rocks are peraluminous to metaluminous, rarely peralkaline, and also present geochemical and mineralogical characteristics of A-type granites (Horbe et al. 1991; Fuck et al. 1993; Lenharo 1998; Costi et al. 2000, 2005; Ferron et al. 2006, 2010). The Paleoproterozoic geological record is completed by the volcano-sedimentary cover of the Urupi Formation and by the ca. 1.79 Ga old mafic-tholeitic rocks of the Quarenta Ilhas Formation (CPRM 2006). In addition, a magmatic event marked by gabbroic intrusions is also recognized in the region but has not been studied in detail yet (Souza \& Nogueira 2009).

The Meso- to Neoproterozoic geological context is represented by the alkaline magmatism of the Seringa Formation (1.07 Ga) and by siliciclastic sedimentary sequence of the Prosperança Formation (CPRM 2006; Cunha et al. 1994; Nogueira 1999), while the Phanerozoic Trombetas and Javari Groups represent the Amazon sedimentary basin (Cunha et al. 1994). In addition, Mesozoic diabase dikes and Cenozoic laterite cover occur in the area as well (CPRM 2006; Horbe et al. 2001).

\section{Effusive Rocks of the Iricoumé Group}

The Iricoumé Group exposures are partially covered by dense rainforest, thick soil cover, by the lake of the Balbina hydroelectric dam, as well as by restricted access areas (e.g. indigenous reserves, Fig. 1B). However, in the farms and agricultural settlement areas, as well as in the mining fronts, excellent exposures of the Iricoumé volcanism are observed, with remarkable preservation of original igneous textures and structures.

Table 1. Isotopic resume available for the Iricoumé volcanism in the southern Guyana shield

\begin{tabular}{|c|c|c|c|c|c|c|}
\hline Region & $\begin{array}{c}\text { Iricoumé volcanism } \\
\text { lithologies }\end{array}$ & $\begin{array}{l}\text { Age } \\
(\mathrm{Ma})\end{array}$ & Method & $\varepsilon_{N d}(t)$ & $\begin{array}{l}\mathrm{NdT}_{\mathrm{DM}} \\
(\mathrm{Ga})\end{array}$ & References \\
\hline SE Roraima state & dacite & 1893 & $\begin{array}{c}\text { zircon }{ }^{207} \mathrm{~Pb} /{ }^{206} \mathrm{~Pb} \\
\text { by evaporation }\end{array}$ & - & - & $\begin{array}{c}\text { Macambira et al. } \\
(2002)\end{array}$ \\
\hline $\begin{array}{l}\text { Pitinga } \\
\text { mining distric } \\
\text { (Amazonas state) }\end{array}$ & $\begin{array}{l}\text { rhyolite, rhyodacites, } \\
\text { ignimbrite }\end{array}$ & $1890-1881$ & $\begin{array}{l}\text { zircon }{ }^{207} \mathrm{~Pb} /{ }^{206} \mathrm{~Pb} \\
\text { by evaporation }\end{array}$ & - & - & $\begin{array}{c}\text { Costi et al. (2000), } \\
\text { Costa (2010), Ferron } \\
\text { (2006) }\end{array}$ \\
\hline $\begin{array}{l}\text { NE Amazonas } \\
\text { state }\end{array}$ & $\begin{array}{l}\text { rhyolite, dacite, } \\
\text { rhyodacites, ignimbrite }\end{array}$ & $1896-1883$ & $\begin{array}{l}\text { zircon }{ }^{207} \mathrm{~Pb} /{ }^{206} \mathrm{~Pb} \\
\text { by evaporation }\end{array}$ & 1.69 to -1.44 & 2.26 to 2.05 & $\begin{array}{c}\text { CRPM (2006), } \\
\text { Valério (2006 and } \\
\text { 2011) }\end{array}$ \\
\hline $\begin{array}{l}\text { NE Amazonas } \\
\text { state }\end{array}$ & $\begin{array}{c}\text { rhyolite, rhyodacites, } \\
\text { andesite, tracky-andesite }\end{array}$ & 1882 & $\begin{array}{l}\text { zircon U-Pb by } \\
\text { LA-MC-ICPMS }\end{array}$ & -5.43 to 0.80 & 2.59 to 2.16 & This paper \\
\hline NW Pará state & andesite, ignimbrite & $1992-1888$ & $\begin{array}{c}\text { zircon }{ }^{207} \mathrm{~Pb} /{ }^{206} \mathrm{~Pb} \\
\text { by evaporation }\end{array}$ & -3.0 to -2.3 & 1.98 to 2.39 & $\begin{array}{c}\text { Barreto et al. } \\
\text { (2012 and 2013) } \\
\text { Klein et al. (2012) }\end{array}$ \\
\hline
\end{tabular}




\section{Petrography}

The acid rocks are rhyolites to rhyodacites, which exhibit red to pink-gray colour, fine to medium-grained porphyritic texture marked by feldspars and quartz-phenocrysts embedded in a fine-grained matrix. Amygdales and fractures filled by late- to post-magmatic minerals, such as epidote, chlorite, carbonate and quartz, are also recognized. Occasionally, the outcrops display magmatic layering with sense of flow to SW (Fig. 2A). The absence of vitroclastic and lithoclastic textures, associated with myrmekite features locally present in these rocks, indicates that these are sub-aerial to aerial lava-flows. However, in some outcrops displaying subhorizontal to curvy-planar layering, where occasional pumice, lithic and fiamme are observed, suggesting that these represent ignimbrite-flows modified by high-temperature rheomorphic process (e.g. Pioli \& Rosi 2005; Andrews \& Branney 2011), which makes it difficult to distinguish between ignimbrite-flows and lava-flows.

In general, the acid rocks present modal contents of alkali-feldspar, plagioclase (oligoclase, $\mathrm{An}_{26-30}$ ) and quartz-phenocrysts varying from 15 to $60 \mathrm{vol} . \%$. They display euhedral to subhedral shapes, with lengths ranging from 0.3 to $3 \mathrm{~mm}$, and commonly exhibit corrosion and resorption features, undulating extinction and are low to moderately fractured (Fig. 2B and C). Bulbous-type myrmekite is a common occurrence in the rims of larger crystals. Quartz-feldspar groundmass presents fine-grained phaneritic to aphanitic textures, with crystals usually oriented in the magmatic-flow circumventing the phenocrysts. They also have subhedral crystals of hornblende, biotite, titanite, zircon, hematite, magnetite, pyrite, ilmenite, allanite and apatite as accessory. Hornblende and biotite crystals are partially chloritized as phenocrysts shapes with lengths ranging from 0.3 to $0.8 \mathrm{~mm}$ in the finer groundmass. Frequently, ilmenite crystals involved by a thin rim of rutile are observed, and may probably represent the product of $\mathrm{Fe}-\mathrm{Ti}$ excess exsolved from the ilemenite structure during temperature decrease or oxygen fugacity variation (e.g. Haggerty 1991).

The intermediate rocks are andesite to trachy-andesite, which exhibit green to green-greyish colour, fine-grained porphyritic texture highlighted by plagioclase-phenocrysts embedded in a fine-grained to aphanitic matrix. The outcrops also display subhorizontal layering marking the magmatic flow and frequent amygdales filled by late- to post-magmatic minerals, such as epidote, chlorite, carbonate and quartz (Fig. 2D). The phenocrysts, ranging from 25 to 50 vol.\%, are mainly plagioclase (andesine, $\mathrm{An}_{38-46}$ ), and rare alkali-feldspar. Plagioclase-phenocrysts have euhedral to subhedral prismatic shapes, with lengths ranging from 1 to $15 \mathrm{~mm}$ usually forming a glomeroporphyritic texture (Fig. 2E). They exhibit albite-carlsbad twinning, are slightly fractured and have corroded edges, moderate decalcification stage marked by epidote and white-mica generation. The groundmass has a fine phaneritic texture and is composed of short lath-shaped plagioclase crystals with subophitic to trachytic texture oriented along the magmatic-flow, circumventing the phenocrysts. They also have partially chloritized hornblende and biotite, as well as pyroxene crystals partially replaced by fibrous amphibole (actinolite-tremolite) form interstitial mineral arrangement. Quartz, titanite, magnetite, ilmenite, pyrite, chalcopyrite and apatite are present as accessory (Fig. 2F).

\section{Whole-Rock Geochemistry}

Whole-rock compositions for acid to intermediate rocks of the Iricoumé Group are shown in Tab. 2 and are discussed below.

The acid rocks present the following contents: $\mathrm{SiO}_{2}=$ $67-72.19$ wt $\%, \mathrm{Al}_{2} \mathrm{O}_{3}=12.94-14.81 \mathrm{wt} \%, \mathrm{Fe}_{2} \mathrm{O}_{3 \text { total }}=$ $3.37-4.07$ wt $\%, \mathrm{CaO}=0.6-2.59$ wt $\%, \mathrm{Na}_{2} \mathrm{O}=3.25-$ $3.88 \mathrm{wt} \%, \mathrm{~K}_{2} \mathrm{O}=4-6 \mathrm{wt} \%$, low contents of $\mathrm{TiO}_{2}, \mathrm{MnO}$, $\mathrm{MgO}, \mathrm{P}_{2} \mathrm{O}_{5}$ and $\mathrm{LOI}<1 \mathrm{wt} \%$, with $\mathrm{Na}_{2} \mathrm{O}+\mathrm{K}_{2} \mathrm{O}$ between 7.75 and 9.39 wt $\%, \mathrm{~K}_{2} \mathrm{O} / \mathrm{Na}_{2} \mathrm{O}$ ratio $\geq 1$, and $\mathrm{FeO}_{\mathrm{t}} / \mathrm{FeO}_{\mathrm{t}}$ $+\mathrm{MgO}$ ratio ranging from 0.78 to 0.95 . They present high $\mathrm{Ba}, \mathrm{Rb}, \mathrm{Zr}$, HREE, and low Sr, Ta, Co and Hf contents. On the $\mathrm{Na}_{2} \mathrm{O}+\mathrm{K}_{2} \mathrm{O}$ versus $\mathrm{SiO}_{2}$ (TAS), as well as $\mathrm{Zr} / \mathrm{TiO}_{2}$ versus $\mathrm{SiO}_{2}$ and $\mathrm{Zr} / \mathrm{TiO}_{2}$ versus $\mathrm{Nb} / \mathrm{Y}$ diagrams, the analyses plot on the rhyolite to rhyodacite fields (Fig. 3), with high alkali contents indicating high-K subalkaline compositions. On the A/NK versus A/CNK diagram, this sample plots between metaluminous to peraluminous fields (Fig. 3D).

On the multi-element spidergrams, these rocks display a pattern similar to upper continental crust, marked by positive $\mathrm{Rb}$, Th, K, La, Ce, Nd and Zr anomalies and strong negative $\mathrm{Ba}, \mathrm{Nb}, \mathrm{Sr}, \mathrm{P}$ and Ti anomalies (Fig. 3E; e.g. Thompson 1982; Rollinson 1993). The REE-normalized patterns are characterized by high LREE $(\mathrm{La}+\mathrm{Ce}=157-226)$ and relatively depleted HREE $(\mathrm{Tm}+\mathrm{Yb}=4.82-6.76)$ contents in relation to the chondrite (Fig. 3G). The REE distribution patterns present moderate fractionation of the LREE group with $(\mathrm{La} / \mathrm{Sm})_{\mathrm{N}}=4.11-5.26$ and absence or light-fractionation of the HRRE group with $(\mathrm{Gd} / \mathrm{Yb})_{\mathrm{N}}=1.24-1.32$, separated by negative Eu anomaly $\left(\mathrm{Eu} / \mathrm{Eu}^{*}=0.21-0.28\right)$.

The acid rocks of the Iricoumé Group have been recognized as A-type (Valério et al. 2009; Ferron et al. 2010; Pierosan et al. 2011a). In the study area, these rocks also present geochemical attributes compatible with A-type magmatism, such as relatively high alkalis $\left(\mathrm{Na}_{2} \mathrm{O}+\mathrm{K}_{2} \mathrm{O}\right), \mathrm{Zr}$, $\mathrm{Th}, \mathrm{Nb}$ and $\mathrm{La}+\mathrm{Ce}$ contents, as well as high $10^{4} \mathrm{Ga} / \mathrm{Al}=$ 2.35 - 2.90 ratios (Collins et al. 1982; Clemens et al. 1986; Whalen et al. 1987; Eby 1992). On the $\mathrm{Zr}$ and $\mathrm{Zr}+\mathrm{Nb}+$ $\mathrm{Ce}+\mathrm{Y}$ versus $10^{4} \mathrm{Ga} / \mathrm{Al}$ diagrams, the samples plot in the 
A-type granite field (Fig. 4A and 4B), and on the $\mathrm{Nb}-\mathrm{Y}-\mathrm{Ce}$ diagram, the samples plot in the $\mathrm{A}_{2}$-subtype field (Fig. 4C), with $\mathrm{Y} / \mathrm{Nb}$ ratios $>1.2$, indicative of magmas emplaced during extensional collapse according to Eby (1992). These geochemical characteristics are consistent with the information obtained about the Iricoumé volcanism in the Pitinga mining district, located about $150 \mathrm{~km}$ to the north of the study area (Fig. 1B).
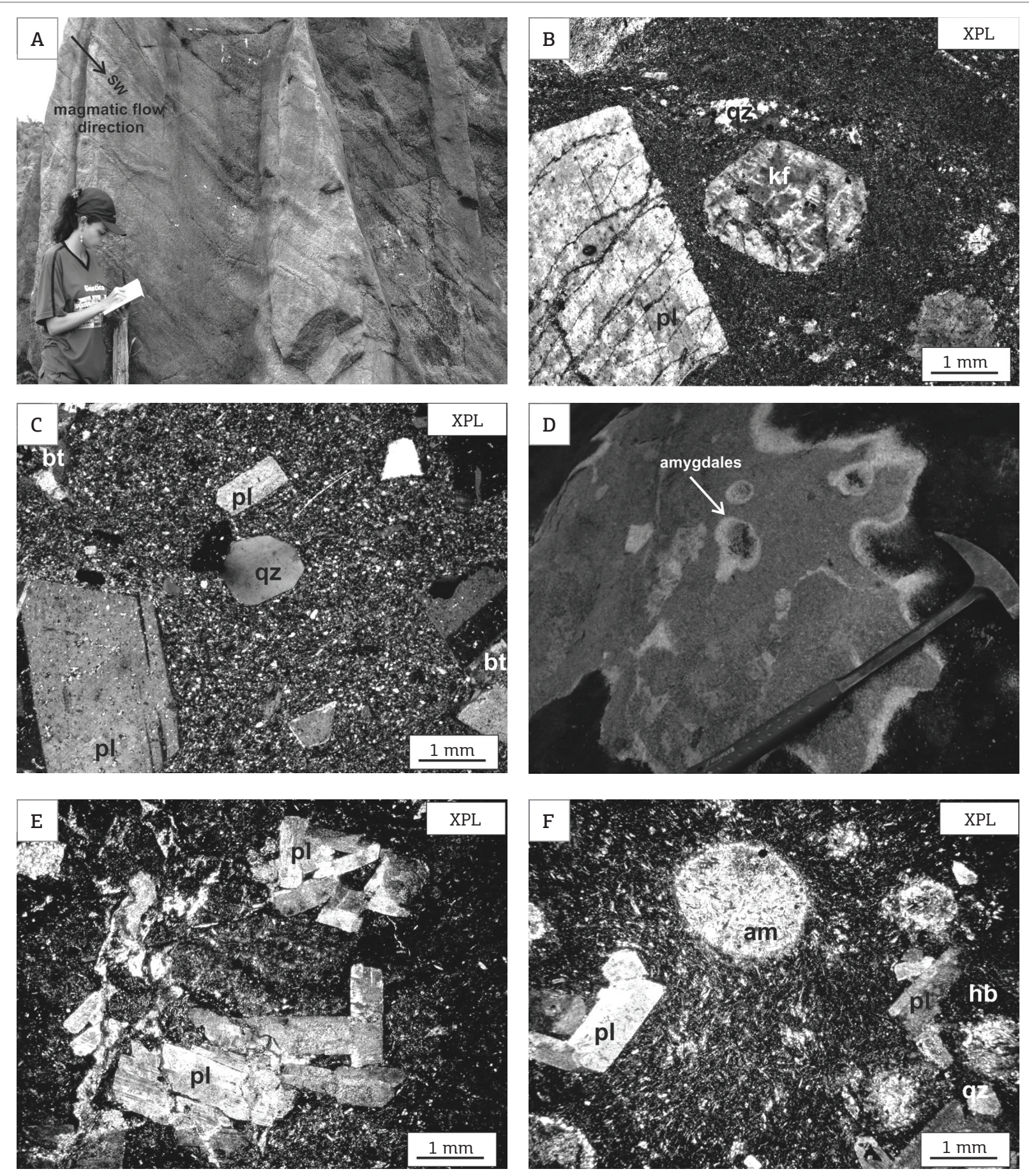

qz: quartz; pl: plagioclase; kf: alkali-feldspar; bt: biotite; hb: hornblende; am: amygdales; XPL: crossed polarisers.

Figure 2. Macroscopic and microscopic features of the effusive rocks of the Iricoumé Group. (A) Magmatic flow layering with sense of flow to SW in acid rocks; (B and C) porphiritic texture in thin section on rhyolites and rhyodacites, respectively; (D) amygdales and fractures filled by late- to post-magmatic minerals in andesites; (E and F) porphyritic to glomeroporphyritic micro-texture with amygdales in andesites. 
The intermediate rocks present the following contents: $\mathrm{SiO}_{2}=55.91-57.69 \mathrm{wt} \%, \mathrm{Al}_{2} \mathrm{O}_{3}=16.66-15.85 \mathrm{wt} \%$, $\mathrm{Fe}_{2} \mathrm{O}_{3 \text { total }}=7-10.64 \mathrm{wt} \%, \mathrm{MgO}=1.13-4.47 \mathrm{wt} \%, \mathrm{CaO}=$ $5.68-7.21 \mathrm{wt} \%, \mathrm{Na}_{2} \mathrm{O}=2.69-3.34 \mathrm{wt} \%, \mathrm{~K}_{2} \mathrm{O}=2.23-$ $3.27 \mathrm{wt} \%$, low contents of $\mathrm{TiO}_{2}$ and $\mathrm{P}_{2} \mathrm{O}_{5}<1.3 \mathrm{wt} \%$, and LOI $=0.80-2.40$ wt $\%$, with $\mathrm{Na}_{2} \mathrm{O}+\mathrm{K}_{2} \mathrm{O}$ between 5.47 and $6.54 \mathrm{wt} \%, \mathrm{~K}_{2} \mathrm{O} / \mathrm{Na}_{2} \mathrm{O}$ ratios are $\leq 1$, and $\mathrm{FeO}_{\mathrm{t}} / \mathrm{FeO}_{\mathrm{t}}+$
$\mathrm{MgO}$ values range from 0.61 to 0.89 . They display relatively high $\mathrm{Ba}, \mathrm{Sr}, \mathrm{Zr}$, Co and HREE contents and low Rb, $\mathrm{Ta}$, Th and $\mathrm{Hf}$ contents. On the $\mathrm{Na}_{2} \mathrm{O}+\mathrm{K}_{2} \mathrm{O}$ versus $\mathrm{SiO}_{2}$ (TAS) diagram the samples plot at the interface between the trachy-andesite, andesite/basaltic and andesite fields, indicating a bimodal magmatism, whose alkali content defines subalkaline composition (Fig. 3A). It is very likely

Table 2. Whole-rock geochemistry composition of the effusive rocks of the Iricoumé Group

\begin{tabular}{|c|c|c|c|c|c|c|c|c|c|c|c|c|c|c|c|c|}
\hline \multirow{2}{*}{$\begin{array}{l}\text { Lithologies } \\
\text { Samples }\end{array}$} & \multicolumn{9}{|c|}{ Andesite to tracky-andesite } & \multicolumn{7}{|c|}{ Rhyolite to rhyodacite } \\
\hline & SVP3A & SVP3A2 & SVP4A & SVP36 & SVP2E & SVP2E2 & SVP2F & SVP3B & C6204 & SVP20 & SVP3C1 & GC3753 & C6604 & GC3735 & GC3717 & GC3715 \\
\hline $\mathrm{SiO}_{2}(\mathrm{wt} \%)$ & 55.91 & 56.12 & 56.20 & 56.37 & 56.58 & 56.76 & 57 & 57.32 & 57.69 & 67.04 & 70.36 & 70.57 & 70.57 & 71 & 71.12 & 72.19 \\
\hline $\mathrm{TiO}_{2}$ & 1.20 & 1.27 & 0.67 & 1.14 & 0.71 & 0.92 & 0.68 & 1.21 & 1.20 & 0.60 & 0.43 & 0.26 & 0.39 & 0.26 & 0.26 & 0.24 \\
\hline $\mathrm{Al}_{2} \mathrm{O}_{3}$ & 16.35 & 16.34 & 16.44 & 16.66 & 16.31 & 15.85 & 16.52 & 16.42 & 16.16 & 14.81 & 13.63 & 13.63 & 14.16 & 13.35 & 13.24 & 12.94 \\
\hline $\mathrm{Fe}_{2} \mathrm{O}_{3 \text { total }}$ & 10.64 & 10.42 & 7.30 & 10.43 & 7.36 & 9.23 & 7 & 9.73 & 10.43 & 4.07 & 3.58 & 4.04 & 3.37 & 4.05 & 4.01 & 3.56 \\
\hline $\mathrm{MnO}$ & 0.22 & 0.16 & 0.11 & 0.19 & 0.10 & 0.13 & 0.10 & 0.15 & 0.18 & 0.08 & 0.07 & 0.11 & 0.07 & 0.07 & 0.10 & 0.09 \\
\hline $\mathrm{MgO}$ & 1.32 & 1.29 & 4.47 & 2.07 & 4.47 & 2.99 & 4.23 & 1.86 & 1.13 & 0.97 & 0.89 & 0.18 & 0.88 & 0.18 & 0.29 & 0.14 \\
\hline $\mathrm{CaO}$ & 7.01 & 7.21 & 6.27 & 5.88 & 6.79 & 5.68 & 6.71 & 6.22 & 6.35 & 2.59 & 2.14 & 1.23 & 1.45 & 0.79 & 0.81 & 0.60 \\
\hline $\mathrm{Na}_{2} \mathrm{O}$ & 2.69 & 2.76 & 2.98 & 2.96 & 2.80 & 3.27 & 2.88 & 3.01 & 3.34 & 3.88 & 3.83 & 3.66 & 3.67 & 3.81 & 3.25 & 3.81 \\
\hline $\mathrm{K}_{2} \mathrm{O}$ & 2.78 & 2.84 & 2.65 & 2.92 & 2.62 & 3.27 & 2.74 & 2.92 & 2.23 & 4.31 & 4.01 & 5.57 & 4.08 & 5.58 & 6.04 & 5.21 \\
\hline $\mathrm{P}_{2} \mathrm{O}_{5}$ & 0.19 & 0.19 & 0.16 & 0.17 & 0.18 & 0.20 & 0.17 & 0.19 & 0.20 & 0.15 & 0.14 & 0.03 & 0.12 & 0.03 & 0.03 & 0.04 \\
\hline LOI & 1.30 & 1.20 & 2.40 & 0.80 & 2 & 1.50 & 1.90 & 0.80 & 0.80 & 1.10 & 0.80 & 0.50 & 0.50 & 0.50 & 0.40 & 0.80 \\
\hline Total & 99.61 & 99.80 & 99.65 & 99.59 & 99.93 & 99.80 & 99.83 & 99.83 & 99.71 & 99.63 & 99.88 & 99.58 & 99.26 & 99.62 & 99.55 & 99.62 \\
\hline $\mathrm{Ba}(\mathrm{ppm})$ & 986 & 914 & 718 & 893 & 703.30 & 833.30 & 701.10 & 718.80 & 965.40 & 1240 & 536.50 & 790 & 531.40 & 600 & 801 & 681 \\
\hline $\mathrm{Rb}$ & 79.90 & 80.60 & 116.90 & 88.70 & 88.20 & 129 & 97.80 & 84.20 & 82 & 152.50 & 137.20 & 216.60 & 130.90 & 189.40 & 230 & 194.60 \\
\hline $\mathrm{Sr}$ & 257.10 & 251.90 & 344.40 & 278.50 & 362.20 & 274.40 & 352.70 & 283.30 & 170.50 & 238.20 & 185.60 & 95.10 & 192.60 & 95.20 & 77.70 & 73.50 \\
\hline $\mathrm{Y}$ & 42.90 & 48.80 & 26.10 & 40 & 27.90 & 40 & 28.20 & 45.50 & 42.10 & 33 & 42.80 & 54.80 & 40.30 & 58.60 & 55.30 & 49.30 \\
\hline $\mathrm{Zr}$ & 271.70 & 266.10 & 221.20 & 265.60 & 207.50 & 257.50 & 214.50 & 251.90 & 248.20 & 335.70 & 368.50 & 476.70 & 329.80 & 447.70 & 472.80 & 430 \\
\hline $\mathrm{Nb}$ & 12.60 & 11.50 & 11.90 & 11.90 & 10.90 & 12.40 & 10.80 & 10.80 & 12 & 16.40 & 17.20 & 21.80 & 15.20 & 22.20 & 22.60 & 21.40 \\
\hline Ta & 0.80 & 0.80 & 0.80 & 0.70 & 0.80 & 1 & 1.10 & 0.80 & 0.70 & 1.30 & 1.40 & 1.40 & 1.20 & 1.50 & 1.50 & 1.30 \\
\hline Co & 46.90 & 54.70 & 43.20 & 30.70 & 37.10 & 44.20 & 41.50 & 46.80 & 25.60 & 127.30 & 46 & 3.40 & 5.70 & 4.10 & 3.80 & 4.60 \\
\hline Ga & 21.40 & 21.30 & 16.60 & 20.80 & 16.81 & 18.50 & 18.10 & 21.10 & 22.10 & 16.20 & 19.60 & 18.80 & 20 & 17.80 & 18.70 & 18.10 \\
\hline $\mathrm{Hf}$ & 7 & 7.50 & 5.20 & 6.90 & 6.30 & 7.50 & 5.50 & 7.40 & 6.90 & 9.20 & 9.40 & 13.40 & 9.40 & 12.60 & 13.10 & 11.80 \\
\hline Th & 8.50 & 10.30 & 10.10 & 8.50 & 12.30 & 12.60 & 11.70 & 7.60 & 9.90 & 17.10 & 19.80 & 23.70 & 18.80 & 25.40 & 25.50 & 22.40 \\
\hline U & 2.80 & 2.70 & 3.80 & 2.60 & 3.50 & 3.30 & 3.70 & 2.60 & 2.10 & 5.60 & 5.10 & 7.30 & 4.90 & 6.40 & 9.20 & 3.10 \\
\hline $\mathrm{Cu}$ & 29.70 & 41.40 & 94.90 & 8.50 & 125.50 & 140.80 & 126.60 & 7.10 & 5 & 5.50 & 11.40 & 7.20 & 5.80 & 4.20 & 6.10 & 20.60 \\
\hline $\mathrm{Zn}$ & 69 & 80 & 47 & 58 & 49 & 90 & 55 & 46 & 90 & 51 & 92 & 77 & 75 & 27 & 63 & 66 \\
\hline $\mathrm{La}$ & 40.30 & 44.40 & 32.70 & 37.50 & 34 & 45 & 34 & 40.20 & 38.50 & 49.30 & 74.50 & 69.30 & 69 & 71.70 & 70.30 & 65.40 \\
\hline $\mathrm{Ce}$ & 89.60 & 93 & 73 & 88.60 & 74.50 & 94.90 & 74.50 & 88.60 & 82.30 & 108.10 & 150.70 & 150.10 & 136.90 & 154.40 & 150.20 & 138.20 \\
\hline Pr & 10.10 & 10.89 & 7.81 & 9.63 & 8.17 & 10.25 & 8.17 & 10.20 & 9.47 & 11.17 & 15.93 & 16.80 & 15.16 & 17.31 & 16.77 & 15.43 \\
\hline $\mathrm{Nd}$ & 41.40 & 42.60 & 31.20 & 41.20 & 29.40 & 37.80 & 29.40 & 38.90 & 39.10 & 42.10 & 55.40 & 63.10 & 56.30 & 65.80 & 62.40 & 58.40 \\
\hline Sm & 7.72 & 8.10 & 4.92 & 7.50 & 5.50 & 7 & 5.50 & 7.70 & 7.90 & 6.74 & 8.90 & 10.34 & 8.90 & 10.94 & 10.41 & 9.46 \\
\hline $\mathrm{Eu}$ & 1.85 & 1.98 & 1.01 & 1.90 & 0.97 & 1.49 & 0.97 & 1.83 & 1.86 & 1.27 & 0.95 & 1.34 & 1.05 & 1.29 & 1.25 & 1.20 \\
\hline Gd & 7.40 & 7.38 & 4.53 & 7.33 & 4.25 & 6.14 & 4.25 & 7.37 & 7.73 & 5.79 & 6.39 & 9.31 & 6.96 & 9.33 & 9.11 & 8.15 \\
\hline $\mathrm{Tb}$ & 1.30 & 1.34 & 0.74 & 1.28 & 0.93 & 1.05 & 0.93 & 1.35 & 1.34 & 0.96 & 1.31 & 1.57 & 1.21 & 1.59 & 1.57 & 1.43 \\
\hline Dy & 7.49 & 8.10 & 4.23 & 7.38 & 2.26 & 6.65 & 4.26 & 7.27 & 7.49 & 5.69 & 6.65 & 8.63 & 6.87 & 8.85 & 8.77 & 8.06 \\
\hline Ho & 1.55 & 1.67 & 0.89 & 1.47 & 0.90 & 1.31 & 0.90 & 1.52 & 1.47 & 1.11 & 1.37 & 1.80 & 1.41 & 1.88 & 1.86 & 1.67 \\
\hline $\mathrm{Er}$ & 4.39 & 4.68 & 2.73 & 4.48 & 2.71 & 4.16 & 2.71 & 4.09 & 4.38 & 3.49 & 4.30 & 5.53 & 3.95 & 5.79 & 5.73 & 5.26 \\
\hline $\mathrm{Tm}$ & 0.69 & 0.77 & 0.40 & 0.64 & 0.45 & 0.58 & 0.45 & 0.69 & 0.64 & 0.56 & 0.66 & 0.89 & 0.65 & 0.92 & 0.88 & 0.78 \\
\hline $\mathrm{Yb}$ & 4.31 & 4.17 & 2.68 & 4.33 & 2.39 & 3.44 & 2.39 & 4.23 & 4.26 & 3.77 & 4.18 & 5.68 & 4.17 & 5.84 & 5.75 & 5.17 \\
\hline $\mathrm{Lu}$ & 0.63 & 0.73 & 0.39 & 0.63 & 0.45 & 0.54 & 0.45 & 0.65 & 0.63 & 0.57 & 0.67 & 0.88 & 0.68 & 0.93 & 0.88 & 0.79 \\
\hline $\mathrm{Na}_{2} \mathrm{O}+\mathrm{K}_{2} \mathrm{O}$ & 5.47 & 5,60 & 5.63 & 5.88 & 5.42 & 6.54 & 5.62 & 5.93 & 5.57 & 8.19 & 7.84 & 9.23 & 7.75 & 9.39 & 9.29 & 9.02 \\
\hline $\mathrm{K}_{2} \mathrm{O} / \mathrm{Na}_{2} \mathrm{O}$ & 1.03 & 1.02 & 0.89 & 0.98 & 0.93 & 1 & 0.95 & 0.97 & 0.66 & 1.11 & 1.04 & 1.52 & 1.11 & 1.46 & 1.85 & 1.36 \\
\hline $\mathrm{FeO}_{\mathrm{t}} / \mathrm{FeO}_{\mathrm{t}}+\mathrm{MgO}$ & 0.87 & 0.87 & 0.61 & 0.82 & 0.61 & 0.74 & 0.61 & 0.82 & 0.89 & 0.79 & 0.79 & 0.94 & 0.78 & 0.94 & 0.92 & 0.95 \\
\hline$(\mathrm{La} / \mathrm{Sm})_{\mathrm{N}}$ & 3.29 & 3.44 & 4.18 & 3.14 & 3.88 & 4.04 & 3.88 & 3.28 & 3.06 & 4.60 & 5.26 & 4.21 & 4.87 & 4.11 & 4.24 & 4.34 \\
\hline$(\mathrm{Gd} / \mathrm{Yb})_{\mathrm{N}}$ & 1.39 & 1.43 & 1.37 & 1.37 & 1.44 & 1.44 & 1.44 & 1.41 & 1.47 & 1.24 & 1.23 & 1.32 & 1.35 & 1.29 & 1.28 & 1.27 \\
\hline $\mathrm{Eu} / \mathrm{Eu}^{*}$ & 0.41 & 0.44 & 0.22 & 0.42 & 0.21 & 0.33 & 0.21 & 0.40 & 0.41 & 0.28 & 0.21 & 0.29 & 0.23 & 0.28 & 0.27 & 0.26 \\
\hline $10^{4} \mathrm{Ga} / \mathrm{Al}$ & 3.10 & 3.09 & 2.41 & 3.02 & 2.44 & 2.68 & 2.62 & 3.06 & 3.20 & 2.35 & 2.84 & 2.73 & 2.90 & 2.58 & 2.71 & 2.62 \\
\hline $\mathrm{Zr}+\mathrm{Nb}+\mathrm{Ce}+\mathrm{Y}$ & 416.80 & 420.50 & 332.20 & 406.10 & 320.80 & 107.30 & 328 & 396.80 & 384.60 & 493.30 & 579.20 & 703.4 & 522.20 & 682.90 & 700.90 & 638.90 \\
\hline
\end{tabular}


A

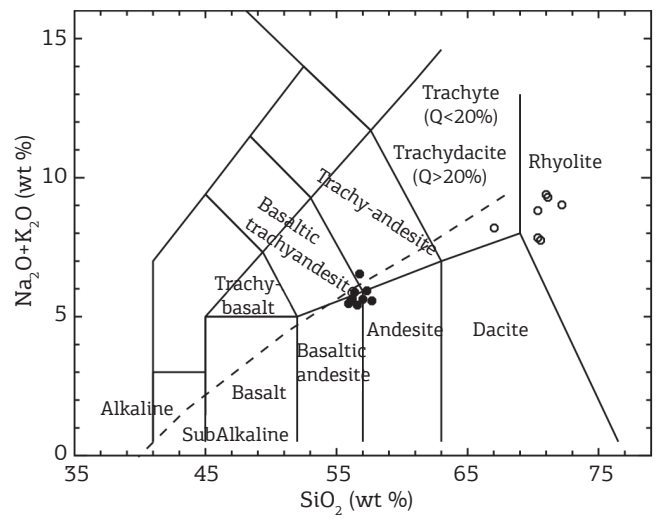

C

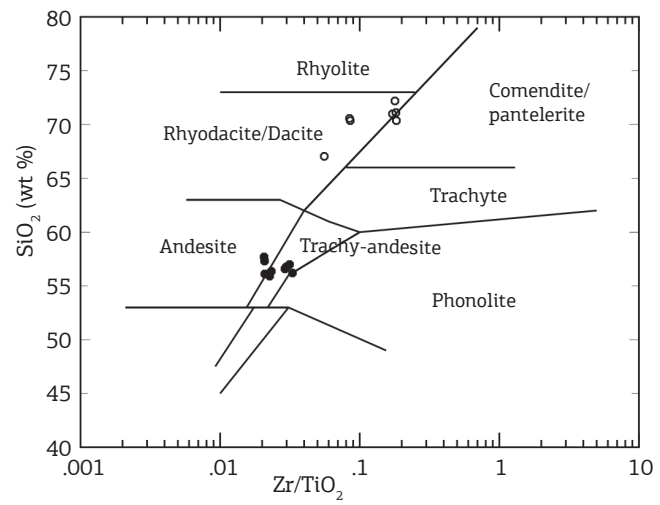

$\mathrm{E}$

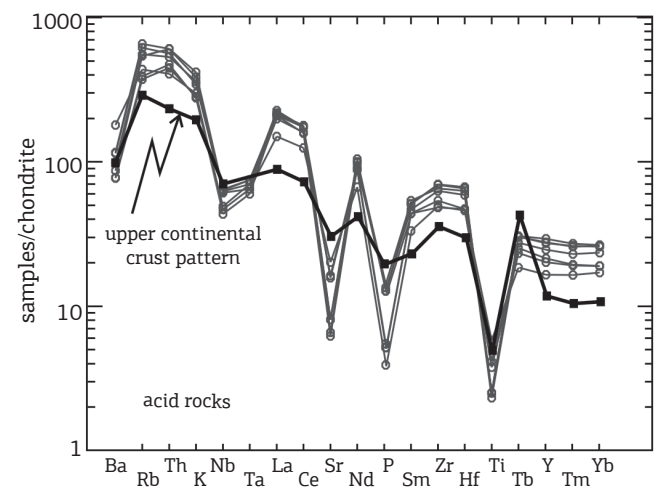

G

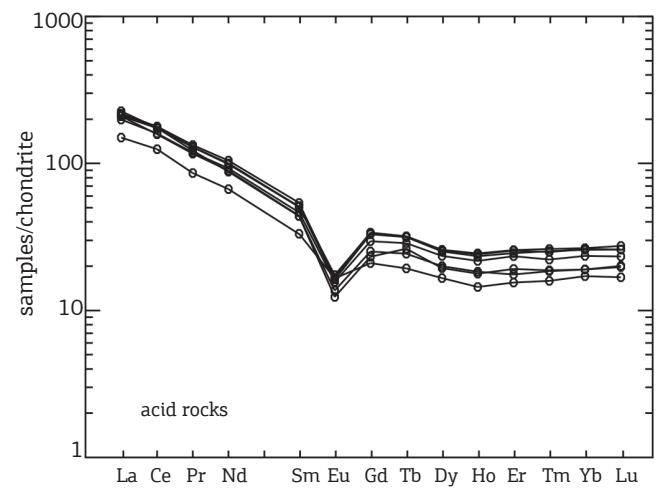

B

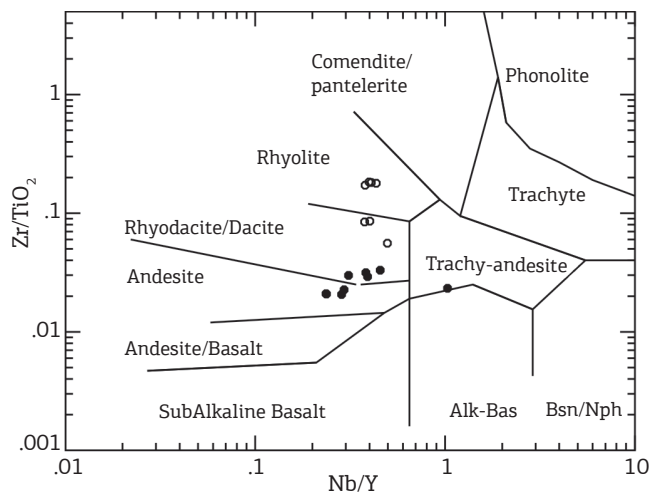

D

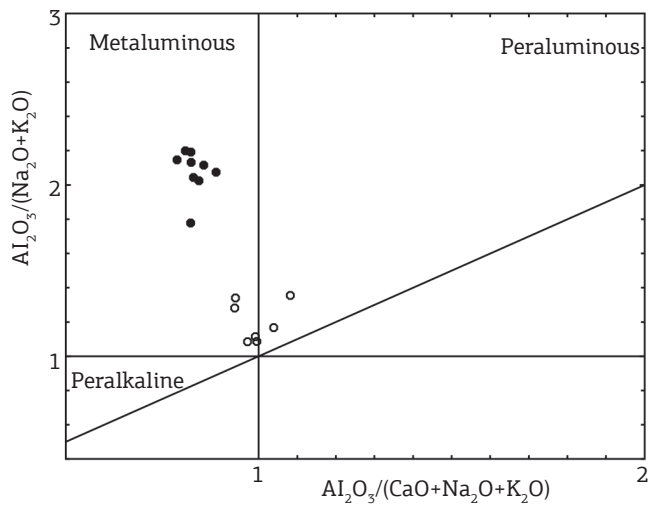

$\mathrm{F}$

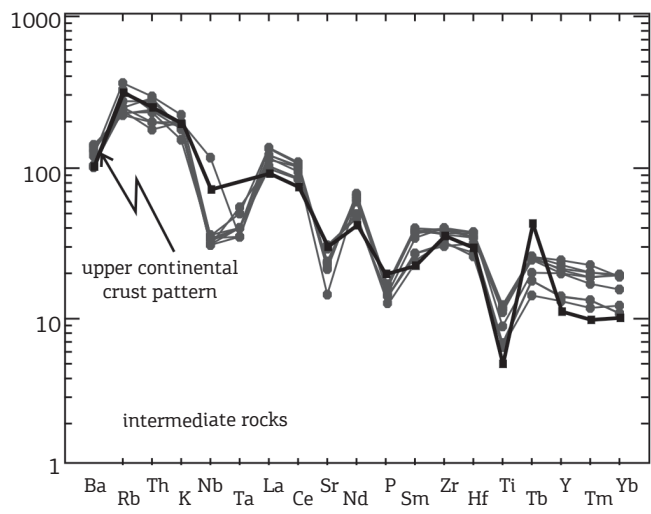

$\mathrm{H}$

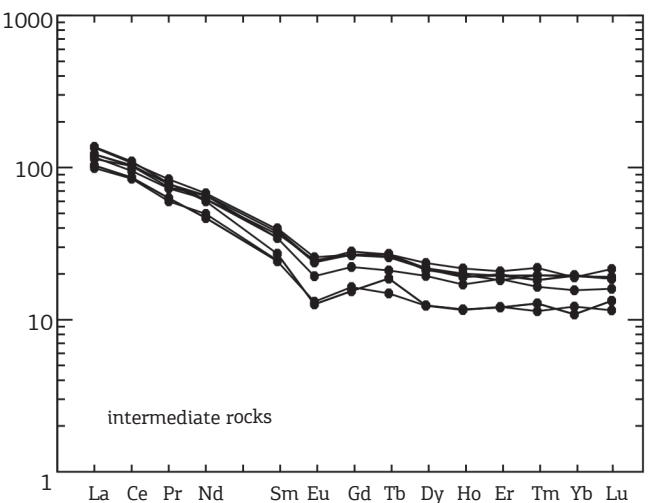

Figure 3. Geochemical characteristics of the volcanic rocks of the Iricoumé Group. (A) $\mathrm{Na}_{2} \mathrm{O}+\mathrm{K}_{2} \mathrm{O}$ versus $\mathrm{SiO}_{2}$ diagram (Le Maitre et al. 1989); (B and C) $\mathrm{Zr} / \mathrm{TiO}_{2}$ versus $\mathrm{Nb} / \mathrm{Y}$ and $\mathrm{Zr} / \mathrm{TiO}_{2}$ versus $\mathrm{SiO}_{2}$ diagrams (Winchester \& Floyd 1977); (D) alumina saturation index diagram (Shand indexes in Maniar \& Piccoli 1989); (E and F) multi-element spidergrams for acid and intermediate rocks (chondrite-normalized pattern of Thompson 1982); (G and H) REE-normalized patterns diagrams for acid and intermediate rocks (chondrite-normalized pattern of Boynton 1984). 
that the chemical compositions of major-elements have been modified by the presence of amygdaloidal texture. In this case, minor- and trace-element correlation diagrams are suitable. Thus, on the $\mathrm{Zr} / \mathrm{TiO}_{2}$ versus $\mathrm{SiO}_{2}$ and $\mathrm{Zr} / \mathrm{TiO}_{2}$

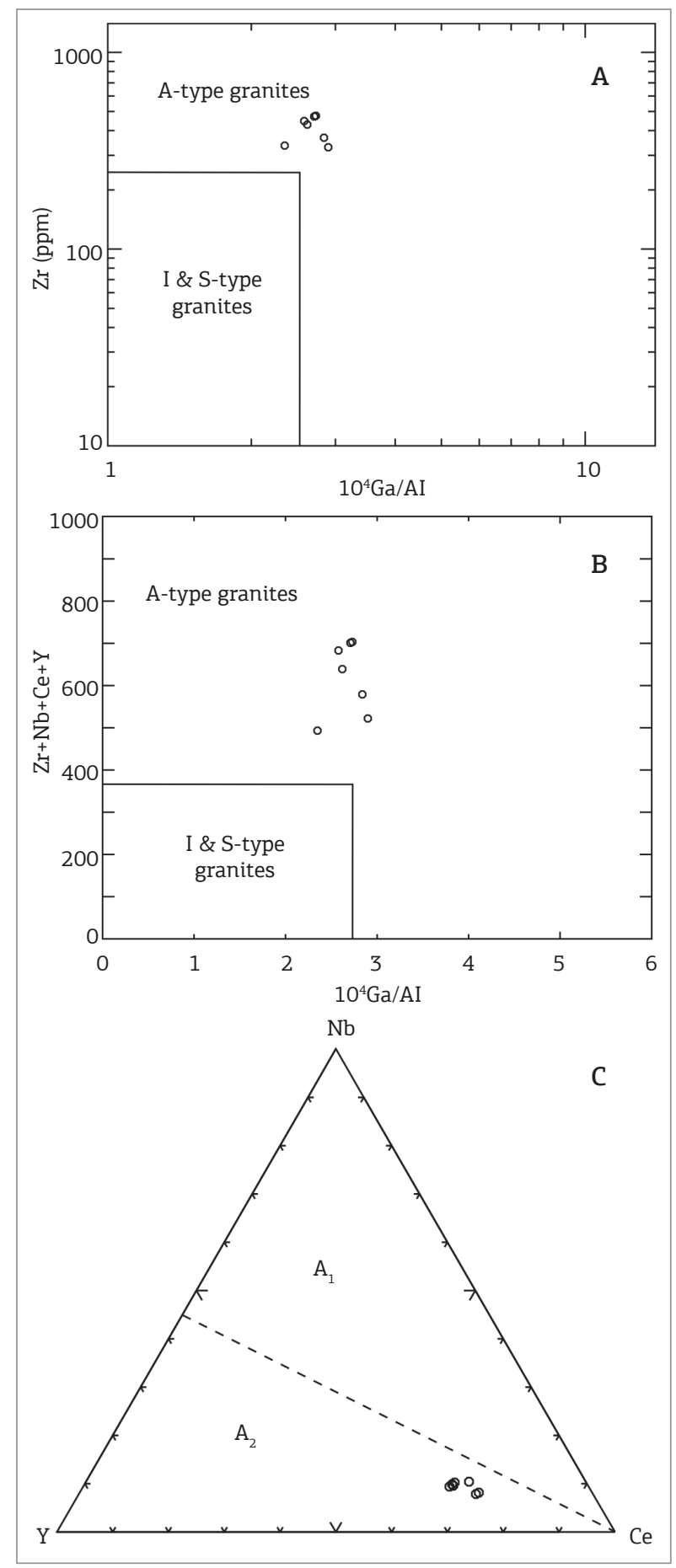

Figure 4. Granitoid discriminating diagram applied to acid rocks of the Iricoumé Group. (A and B) $\mathrm{Zr}$ and $\mathrm{Zr}+$ $\mathrm{Nb}+\mathrm{Ce}+\mathrm{Y}$ versus $10^{4} \mathrm{Ga} / \mathrm{Al}$ plot (Whalen et al. 1987); (C) $\mathrm{Nb}$ versus $\mathrm{Y}$ versus $\mathrm{Ce}$ triangular diagram for A-type granitoids (Eby 1992). versus $\mathrm{Nb} / \mathrm{Y}$ diagrams, these rocks tend to plot in andesite to trachy-andesite fields (Fig. 3B and 3C). On the A/NK versus $\mathrm{A} / \mathrm{CNK}$ diagram, this sample plots in the metaluminous field (Fig. 3D).

In the multi-element spidergrams, these rocks also demonstrate a pattern similar to upper continental crust, marked by positive $\mathrm{Rb}$, Th, K, La, Ce, Nd, Sm, Zr and Hf anomalies and negative $\mathrm{Ba}, \mathrm{Nb}, \mathrm{Ta}, \mathrm{Sr}, \mathrm{P}$ and $\mathrm{Ti}$ anomalies (Fig. 3F, e.g. Thompson 1982; Rollinson 1993). The REE-normalized patterns are characterized by moderate LREE $(\mathrm{La}+\mathrm{Ce}=105-140)$ and relatively depleted $\operatorname{HREE}(\mathrm{Tm}+\mathrm{Yb}=2.80-5)$ contents in relation to the chondrite (Fig. 3H). The REE distribution patterns also present moderate fractionation of the LREE group with $(\mathrm{La} / \mathrm{Sm})_{\mathrm{N}}=3.06-4.18$ and absence or light-fractionation of the HRRE group with $(\mathrm{Gd} / \mathrm{Yb})_{\mathrm{N}}=1.37-1.47$, separated by negative Eu anomaly $\left(\mathrm{Eu} / \mathrm{Eu}^{*}=0.21-0.44\right)$.

\section{Geochronology (U-Pb and Sm-Nd)}

$\mathrm{U}-\mathrm{Pb}$ and $\mathrm{Sm}-\mathrm{Nd}$ data for the volcanic rocks of the Iricoumé Group are listed in Tabs. 3 and 4, and are discussed below.

The rhyolite SVP3C sample (810915/9823114 UTM coordinates) was chosen for U-Pb by LA-MC-ICPMS isotopic analyses and a total of 28 zircon crystals were handpicked. Zircon crystals are euhedral to subhedral, pale yellow to pale pink, zoned and displaying short- to long-prismatic shape $(180-500 \mu \mathrm{m})$, with few to moderate micro-inclusions or fractures. Typical fine oscillatory zoning may be observed (Fig. 5). The U-Pb results obtained for 21 analyzed zircon crystals allowed the calculation of a discordia line indicating an upper intercept age of $1882 \pm$ $11 \mathrm{Ma}$, which is here interpreted as the crystallization age of the rhyolite (Fig. 5). These data are consistent with the $\mathrm{Pb}-\mathrm{Pb}$ interval age (1881 - $1896 \mathrm{Ma}$ ) known for the Iricoumé volcanism in this region (Tab. 1; e.g. Macambira et al. 2002; Valério 2006; Ferron 2006; Berreto et al. 2013).

The whole-rock $\mathrm{Sm}-\mathrm{Nd}$ analyses were performed on seven selected samples, three acid (SVP3C1, GC3735, C6604) and four intermediate volcanic rocks samples (SVP2E, SVP4A, SVP3A, SVP3B).

As all samples showed ${ }^{147} \mathrm{Sm} /{ }^{144} \mathrm{Nd}$ ratios in the range of $0.10-0.12$, these data were useful for calculation of $\mathrm{T}_{\mathrm{DM}}$ model ages. For the acid rock samples, the $\varepsilon_{\mathrm{Nd}}(t=$ $1882 \mathrm{Ma}$ ) values ranged from -4.43 to 0.03 , while $\mathrm{Nd} \mathrm{T}_{\mathrm{DM}}$ model ages ranged from 2.59 to $2.16 \mathrm{Ga}$, and fractionation indexes $\left(f_{\mathrm{Sm} / \mathrm{Nd}}\right)$ between -0.38 and -0.51 . The $f \mathrm{Sm} / \mathrm{Nd}$ values were calculated using the Goldstein et al. (1984) equation. For the intermediate rock samples, for which zircon ages are not available, the age of the rhyolite was assumed as their crystallization age, based on stratigraphic correlations. The $\varepsilon_{\mathrm{Nd}}(t=1882 \mathrm{Ma})$ between -3.74 and 0.80 , whereas $\mathrm{T}_{\mathrm{DM}}$ 
model ages are between 2.44 and $2.13 \mathrm{Ga}$. The fractionation indexes $(f \mathrm{Sm} / \mathrm{Nd})$ are between -0.34 and -0.45 . This data is also consistent with the $\mathrm{Sm}-\mathrm{Nd}$ data known for Iricoumé volcanism in this region (Tab. 1).

The $\mathrm{NdT}_{\mathrm{DM}}$ model age values for all samples are between 2.59 and $2.16 \mathrm{Ga}$. The $\varepsilon_{\mathrm{Nd}}(t)$ values from -4.78 to 0.03 indicate that the magmatic evolution was dominantly produced by related ensialic reworking of older Paleoproterozoic crust, with some degree of mixing of the felsic magmas with Paleoproterozoic (1.88 Ga) mantle-derived magmas. The diagram $\varepsilon_{\mathrm{Nd}}$ versus time summarizes the $\mathrm{Nd}$ evolution patterns provided by the rocks samples investigated (Fig. 6), and it suggests the existence of two isotopically distinct groups: (1) the group (C6604, SVP2E, SVP3A, SVP3B) display $\varepsilon_{N d}(t)$ values close to zero, suggesting a more contribution juvenile; and (2) the group (SVP3C1, GC3735, SVP4A) have $\varepsilon_{\mathrm{Nd}}(t)$ values that are substantially more negative, between -3.4 and -5.5 , indicating increased participation of crustal material.

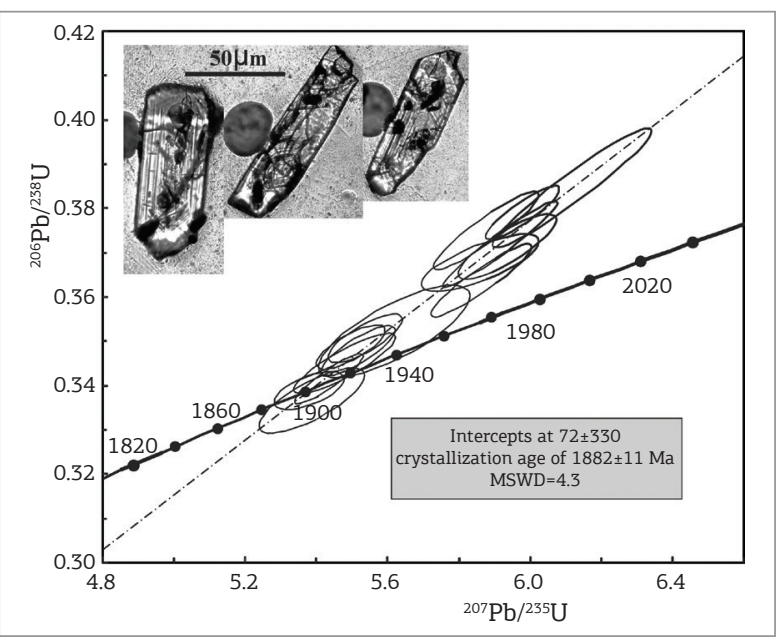

Figure 5. Images transmitted light microscopy images of zircon and concordia diagram rhyolite sample SVP3C showing a crystallization age of $1882 \pm 11 \mathrm{Ma}$.

Table 3. LA-MC-ICPMS U-Pb data for sample SVP3C

\begin{tabular}{|c|c|c|c|c|c|c|c|c|c|c|c|c|c|c|c|c|}
\hline \multicolumn{8}{|c|}{ Isotope ratios } & \multicolumn{6}{|c|}{ Age (Ma) } & \multirow[b]{2}{*}{ Rho } & \multirow[b]{2}{*}{ Th/U } & \multirow[b]{2}{*}{ Conc. (\%) } \\
\hline $\begin{array}{l}\text { Zircon } \\
\text { crystals }\end{array}$ & ${ }^{206} \mathrm{~Pb} /{ }^{204} \mathrm{~Pb}$ & ${ }^{207} \mathrm{~Pb} /{ }^{206} \mathrm{~Pb}$ & $1 \sigma \%$ & ${ }^{207} \mathrm{~Pb} /{ }^{238} \mathrm{U}$ & $1 \sigma \%$ & ${ }^{206} \mathrm{~Pb} /{ }^{238} \mathrm{U}$ & $1 \sigma \%$ & ${ }^{207} \mathrm{~Pb} /{ }^{206} \mathrm{~Pb}$ & $\begin{array}{c}1 \sigma \\
\text { (abs) }\end{array}$ & ${ }^{207} \mathrm{~Pb} /{ }^{235} \mathrm{U}$ & $\begin{array}{c}1 \sigma \\
\text { (abs) }\end{array}$ & ${ }^{206} \mathrm{~Pb} /{ }^{238} \mathrm{U}$ & $\begin{array}{c}1 \sigma \\
\text { (abs) }\end{array}$ & & & \\
\hline $03 Z 1$ & 201630 & 0.11539 & 0.3 & 5.9164 & 1.1 & 0.37187 & 1.1 & 1886.0 & 5.2 & 1963.6 & 9.6 & 2038.2 & 18.6 & 0.96 & 0.37 & 108.07 \\
\hline $05 Z 3$ & 393153 & 0.11504 & 0.4 & 5.5176 & 0.8 & 0.34784 & 0.7 & 1880.6 & 7.2 & 1903.3 & 6.6 & 1924.3 & 10.9 & 0.82 & 0.42 & 102.33 \\
\hline $07 Z 5$ & 59199 & 0.11433 & 0.4 & 5.4968 & 0.7 & 0.34870 & 0.6 & 1869.3 & 7.5 & 1900.1 & 6.1 & 1928.4 & 9.7 & 0.76 & 0.41 & 103.16 \\
\hline $08 Z 6$ & 117941 & 0.11331 & 0.4 & 6.0893 & 3.2 & 0.38975 & 3.2 & 1853.2 & 6.6 & 1988.7 & 27.7 & 2121.7 & 57.0 & 0.99 & 0.38 & 114.48 \\
\hline $09 \mathrm{Z7}$ & 288412 & 0.11514 & 0.5 & 5.3800 & 0.7 & 0.33890 & 0.5 & 1882.0 & 9.6 & 1881.7 & 6.4 & 1881.4 & 8.4 & 0.61 & 0.27 & 99.97 \\
\hline $10 Z 8$ & 265204 & 0.11331 & 0.5 & 5.2940 & 0.7 & 0.33886 & 0.6 & 1853.1 & 8.3 & 1867.9 & 6.3 & 1881.2 & 9.4 & 0.85 & 0.24 & 101.51 \\
\hline $13 Z 9$ & 178249 & 0.11544 & 0.3 & 5.4353 & 0.7 & 0.34148 & 0.7 & 1886.7 & 4.9 & 1890.4 & 6.2 & 1893.8 & 10.9 & 0.91 & 0.30 & 100.37 \\
\hline $14 \mathrm{Z} 10$ & 79442 & 0.11570 & 0.3 & 5.1474 & 0.6 & 0.32268 & 0.6 & 1890.7 & 4.9 & 1844.0 & 5.5 & 1802.8 & 9.1 & 0.87 & 0.41 & 95.35 \\
\hline $16 Z 12$ & 108987 & 0.11354 & 0.8 & 5.4625 & 1.3 & 0.34894 & 1.0 & 1856.8 & 14.3 & 1894.7 & 10.9 & 1929.5 & 16.5 & 0.90 & 0.30 & 103.92 \\
\hline $19 Z 15$ & 26143 & 0.11689 & 0.7 & 5.3369 & 1.0 & 0.33113 & 0.8 & 1909.2 & 11.7 & 1874.8 & 8.9 & 1843.8 & 13.1 & 0.76 & 0.31 & 96.57 \\
\hline $20 Z 16$ & 218499 & 0.11522 & 0.7 & 5.4806 & 1.1 & 0.34500 & 0.8 & 1883.3 & 12.6 & 1897.6 & 9.2 & 1910.7 & 13.3 & 0.87 & 0.31 & 101.45 \\
\hline $24 Z 18$ & 31612 & 0.11441 & 0.3 & 5.9788 & 0.7 & 0.37899 & 0.6 & 1870.7 & 5.2 & 1972.8 & 6.2 & 2071.6 & 11.5 & 0.89 & 0.37 & 110.74 \\
\hline $27 Z 21$ & 51887 & 0.11609 & 0.7 & 5.3878 & 1.1 & 0.33660 & 0.9 & 1896.9 & 12.4 & 1882.9 & 9.6 & 1870.3 & 14.4 & 0.77 & 0.38 & 98.60 \\
\hline $28 Z 22$ & 4679 & 0.11691 & 0.3 & 5.8626 & 1.0 & 0.36369 & 0.9 & 1909.5 & 6.2 & 1955.7 & 8.5 & 1999.7 & 15.8 & 0.93 & 0.66 & 104.72 \\
\hline $30 Z 24$ & 5236 & 0.11676 & 0.8 & 6.0914 & 1.2 & 0.37836 & 1.0 & 1907.3 & 13.7 & 1989.0 & 10.7 & 2068.6 & 16.9 & 0.90 & 0.27 & 108.46 \\
\hline $33 Z 25$ & 24738 & 0.11570 & 1.0 & 5.6184 & 1.5 & 0.35218 & 1.2 & 1890.9 & 17.3 & 1918.9 & 13.3 & 1945.0 & 20.3 & 0.77 & 0.26 & 102.86 \\
\hline $34 Z 26$ & 108631 & 0.11595 & 0.5 & 5.9362 & 0.9 & 0.37131 & 0.8 & 1894.7 & 8.9 & 1966.5 & 8.2 & 2023.5 & 14.1 & 0.83 & 0.31 & 107.43 \\
\hline $35 Z 27$ & 946051 & 0.11368 & 0.4 & 5.8771 & 1.0 & 0.37497 & 1.0 & 1859.0 & 6.8 & 1957.9 & 8.9 & 2052.7 & 16.8 & 0.92 & 0.23 & 110.42 \\
\hline $36 Z 28$ & 187485 & 0.11559 & 0.9 & 5.8598 & 1.1 & 0.36767 & 0.7 & 1889.1 & 16.3 & 1955.3 & 10.0 & 2018.4 & 12.3 & 0.75 & 0.23 & 106.85 \\
\hline $37 Z 29$ & 2306 & 0.11539 & 0.4 & 6.1180 & 1.5 & 0.38455 & 1.4 & 1885.9 & 7.6 & 1992.8 & 13.0 & 2097.5 & 25.6 & 0.96 & 0.35 & 111.22 \\
\hline $39 Z 31$ & 135266 & 0.11452 & 0.4 & 5.5367 & 0.8 & 0.35064 & 0.6 & 1872.4 & 7.8 & 1906.3 & 6.6 & 1903.7 & 10.6 & 0.79 & 0.43 & 103.49 \\
\hline
\end{tabular}

Table 4. Sm-Nd data for the effusive rocks of the Iricoumé Group

\begin{tabular}{l|c|c|c|c|c|c|c|c|c}
\hline Samples & Lithologies & $\begin{array}{c}\mathbf{S m} \\
(\mathbf{p p m})\end{array}$ & $\begin{array}{c}\mathbf{N d} \\
(\mathbf{p p m})\end{array}$ & ${ }^{147} \mathbf{S m} /{ }^{144} \mathbf{N d}$ & $\begin{array}{c}{ }^{143} \mathbf{N d} / \mathbf{1 4} \mathbf{N d} \\
( \pm \mathbf{2 S E})\end{array}$ & $\begin{array}{c}\varepsilon_{\mathbf{N d}} \\
(\mathbf{0})\end{array}$ & $\begin{array}{c}\varepsilon_{\mathbf{N d}} \\
(\mathbf{t}=\mathbf{1 . 8 8 2} \mathbf{M a})\end{array}$ & $\begin{array}{c}\mathbf{T}_{\mathbf{D M}} \\
(\mathbf{G a})\end{array}$ & $\mathbf{f} \mathbf{S m} / \mathbf{N d}$ \\
\hline SVP3C1 & Rhyodacite & 10.29 & 55.06 & 0.1129 & $0.511425 \pm 7$ & -23.66 & -3.43 & 2,46 & -0.43 \\
\hline GC3735 & Rhyolite & 5.93 & 29.60 & 0.1212 & $0.511477 \pm 7$ & -22.64 & -5.43 & 2.59 & -0.38 \\
\hline C6604 & Rhyolite & 8.68 & 55.04 & 0.0954 & $0.511385 \pm 11$ & -24.44 & 0.03 & 2.16 & -0.51 \\
\hline SVP2E & Andesite & 5.33 & 29.65 & 0.1088 & $0.511516 \pm 11$ & -21.89 & -0.65 & 2.25 & -0.45 \\
\hline SVP4A & Andesite & 5.14 & 28.35 & 0.1097 & $0.511370 \pm 8$ & -24.73 & -3.74 & 2.47 & -0.44 \\
\hline SVP3A & Andesite & 8.00 & 39.23 & 0.1234 & $0.511771 \pm 9$ & -16.92 & 0.80 & 2.19 & -0.37 \\
\hline SVP3B & Andesite & 8.28 & 38.61 & 0.1296 & $0.511770 \pm 12$ & -16.93 & -0.73 & 2.34 & -0.34 \\
\hline
\end{tabular}




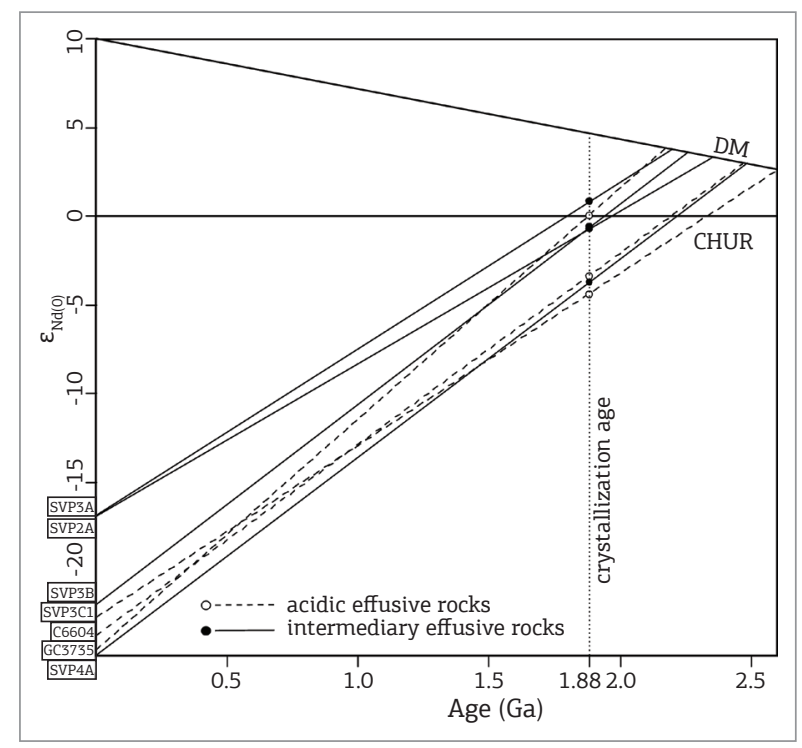

Figure 6. $\varepsilon_{\mathrm{Nd}}(0)$ versus time $(\mathrm{Ga})$ diagram applied to acidic and intermediary effusive rocks from Iricoumé Group. Prepared in accordance to depleted mantle model of De Paolo (1981).

These $\mathrm{Sm}-\mathrm{Nd}$ isotopic data are interpreted as indicative of reworking, during the Orosian, of a previous Rhyacian or Siderian juvenile continental crust (Transamazonian crust crust-forming event), or with probable contamination by Archean crust (Marques et al. 2007).

\section{DISCUSSION}

The volcanic rocks of the Iricoumé Group present some important geochemical differences especially on aluminum saturation index (A/NK versus $\mathrm{A} / \mathrm{CNK}), \mathrm{K}_{2} \mathrm{O} / \mathrm{Na}_{2} \mathrm{O}$ ratio, alkali contents $\left(\mathrm{Na}_{2} \mathrm{O}+\mathrm{K}_{2} \mathrm{O}\right)$, as well as $\mathrm{Zr}+\mathrm{Nb}+\mathrm{Ce}+\mathrm{Y}$ and contents. On Harker diagrams, the $\mathrm{SiO}_{2}$ contents clearly indicate the bimodal nature of the magmatism with a compositional gap between intermediate $\left(\mathrm{SiO}_{2}<57.7 \mathrm{wt} \%\right)$ and acid rocks $\left(\mathrm{SiO}_{2}>67 \mathrm{wt} \%\right)$, without delineation of geochemical common trends, suggesting different evolution and magmatic sources (Fig. 7). The progressive increase of $\mathrm{SiO}_{2}$ is followed by decrease in $\mathrm{Al}_{2} \mathrm{O}_{3}, \mathrm{Fe}_{2} \mathrm{O}_{3 \text { tot. }}, \mathrm{MgO}$, $\mathrm{CaO}, \mathrm{TiO}_{2}, \mathrm{P}_{2} \mathrm{O}_{5}$ and $\mathrm{Sr}$ contents, indicating that plagioclase, hornblende, pyroxene, biotite and apatite have an important role in progressive fractional crystallization, especially in intermediate rocks. On the other hand, $\mathrm{Na}_{2} \mathrm{O}$, $\mathrm{K}_{2} \mathrm{O}$ and $\mathrm{Rb}$ contents tend to show a positive correlation with increase of $\mathrm{SiO}_{2}$, suggesting action of the plagioclase and alkali-feldspar fractionation, mainly in acid rocks. Ta, $\mathrm{Nb}, \mathrm{Zr}$, Ce and Y behave as incompatible elements with their contents increase towards to acid rocks, probably likely to alkali-feldspar fractionation or to accumulation of accessory minerals.

The inverse correlation between the less- and more-differentiated rocks on the $\mathrm{Rb}$ versus $\mathrm{Sr}$ diagram is also noteworthy (Fig. 8), suggesting that plagioclase and alkali-feldspar were the main minerals fractionated during the magmatic evolution. On Hf + La + Ce versus Zr diagram (Fig. 8), note a positive correlation marked by progressive enrichment of HFS elements towards more differentiated rocks, which is the result of fractionation from the accumulation of incompatible elements likely to accessory minerals structure, such as zircon, allanite, apatite and titanite. These petrogenetic characteristic are consistent with the data available for Iricoumé volcanism in the Pitinga mining district (Ferron et al. 2010; Pierosan et al. 2011a).

Although typical basaltic composition rocks have not been registered in this region, it is possible that some rocks classified here as andesites are originally basalts modified by later hydrothermal process or amygdaloidal texture presence. This is suggested by the contents of some elements that are considered to be unusual for typical andesite, such as variation in $\mathrm{MgO}$, slightly depleted $\mathrm{Na}_{2} \mathrm{O}$, high $\mathrm{K}_{2} \mathrm{O}, \mathrm{CaO}$ and LOI on whole-rock geochemistry (Tab. 1). Therefore, it is possible that some basaltic rocks had their original chemical composition modified and moved towards the andesitic composition. For further evaluation of crustal contamination, $\mathrm{Zr} / \mathrm{Y}$ versus $\mathrm{Nb} / \mathrm{Y}$ and $\mathrm{Zr} / \mathrm{Y}$ versus $\mathrm{Ce} / \mathrm{Y}$ ratios of studied andesite samples along with average crust and primordial mantle are plotted (Fig. 8). The samples plot on a trend very close to average crust, which suggests crustal contamination. This pattern associated with negative $\varepsilon_{\mathrm{Nd}}(t)$ data indicates that these andesites are probably derived either from a modified mantle source, or the original magmas were contaminated with older crustal rocks during ascent and crystallization.

With respect to the tectonic setting of origin, the multicationic $\mathrm{R} 1$ versus $\mathrm{R} 2$ values diagram indicate that the acid rocks are roughly distributed between late-orogenic and post-orogenic, whereas on the $\mathrm{Rb}$ versus $\mathrm{Y}+\mathrm{Nb}$ diagram, the samples plot on the post-collisional or within-plate domain (Fig. 9A and 9B). This geochemical characteristic is also consistent with the data available for Iricoumé felsic rocks in the Pitinga mining district (Ferron et al. 2010; Pierosan et al. 2011a). On the other hand, for intermediate rocks tectonic discriminant diagrams applied to basalts, such as $\mathrm{Nb}^{*} 2$ versus $\mathrm{Z} / 4$ versus $\mathrm{Y}$ ternary (Meschede 1986) and $\mathrm{Zr} / \mathrm{Y}$ versus $\mathrm{Zr}$ (Rollinson 1993), were used. The samples plot in the within-plate basalt fields (Fig. 9C and 9D).

Several geological mechanisms have been suggested to explain the association between A-type granite/rhyolite with basalt in post-collisional or in within-plate tectonic settings (Whalen et al. 1996; Creaser et al. 1991; Turner 

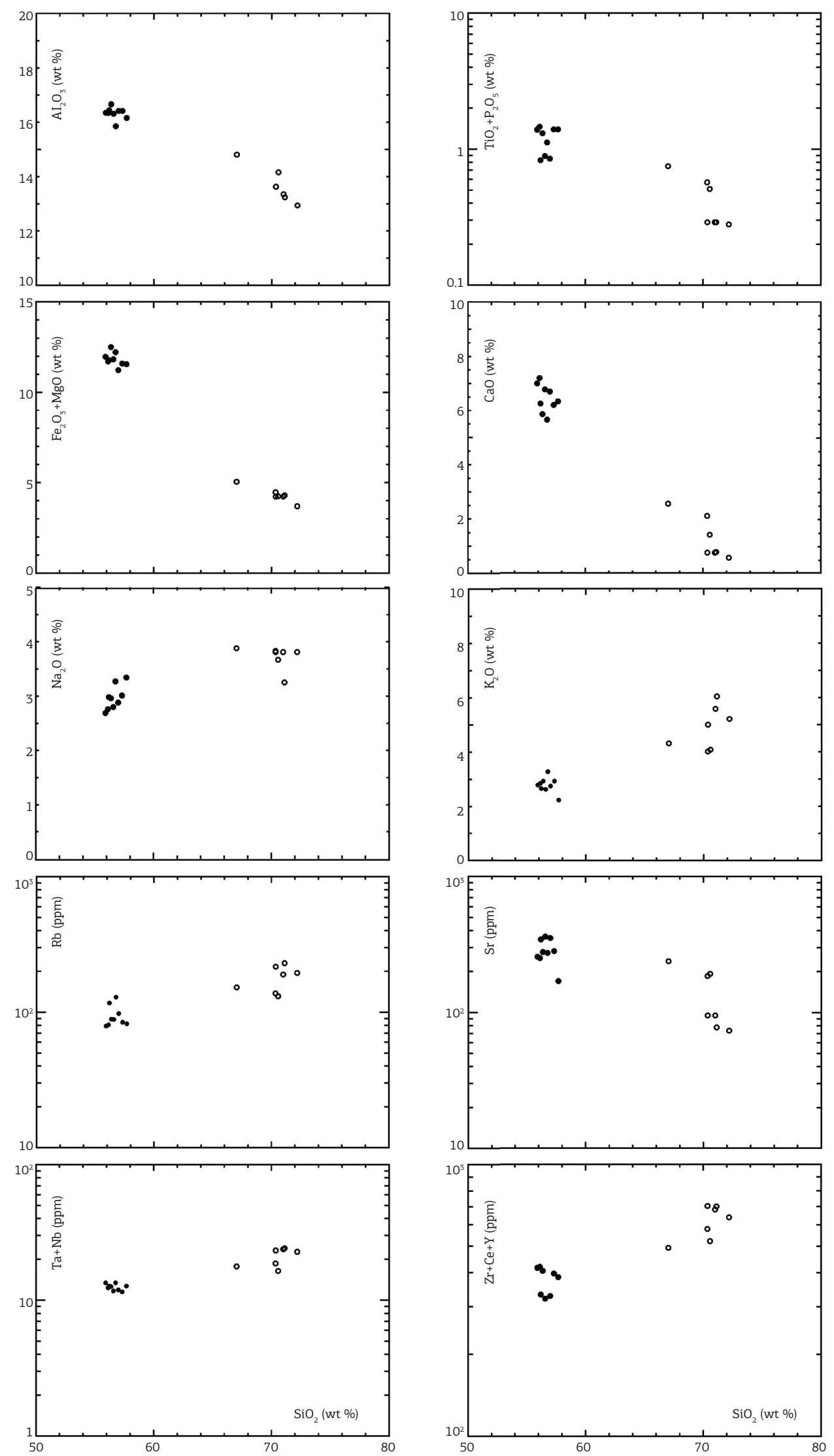

Figure 7. Harker-type diagrams applied to acidic and intermediary effusive rocks from Iricoumé Group (blank circle $=$ acid rocks and filled circle $=$ intermediate rocks). 
et al. 1992; Dall'Agnol et al. 1994; Bonin 2007). In the southernmost Guyana shield has been recognized that I and A-type magmatism took place between 1.92 and $1.86 \mathrm{Ga}$ in distinct tectonic settings. During the initial stages, the I-type magmatism is represented by the Água Branca Intrusive Suite emplaced in syn- to post-collisional uplift setting (Valério 2006, 2011; Valério et al. 2006, 2009). This was followed by a more-evolved stage, represented by the Iricoumé-Mapuera association emplaced in within-plate or post-collisional tectonic settings as volcano-plutonic ring systems associated to an extensional event (Valério et al. 2009; Ferron et al. 2010; Pierosan et al. 2011a). Other authors (e.g. Almeida 2006; Almeida et al. 2007), on the other hand, suggest that the emplacement of the Água Branca and Mapuera suites occurred during the same tectonic stage in response to asthenosphere rise producing mantle-derived magmas which promoted extensive re-melting of the lower crust during underplating.

The $\varepsilon_{\mathrm{Nd}}(t)$ values presented in this paper suggested mixing of two-magmas sources (mantle- and crustal-derived magmas) for the Iricoumé volcanism. Pierosan et al. (2009) suggest that the slab-breakoff tectonic model could have been involved to explain the participation of two magmatic sources during a post-collisional setting, promoting asthenosphere uplift and leading to the melting of the metasomatized overriding mantle lithosphere (e.g. Davies \& Blanckenburg 1995). Another alternative tectonic model would involve mantle plume and lithospheric delamination (e.g. Saunders et al. 1992; Elkins-Tanton 2005; Pirajno 2007; Pirajno \& Hoatson 2012), but the lack of additional isotopic (Sm-Nd, Sr-Sr, Lu-Hf) and petrological data, as well as seismic tomography investigations, still inhibit the better understanding of the tectonic evolution for the region.

In the southernmost Guyana shield, the extensive Iricoumé volcanism is associated with caldera system complex, identified mainly in the Pitinga mining district (Ferron et al. 2002; Pierosan et al. 2011b), which displays several eruptive conduits, as well as collapse structures, favouring the larger production of pyroclastic
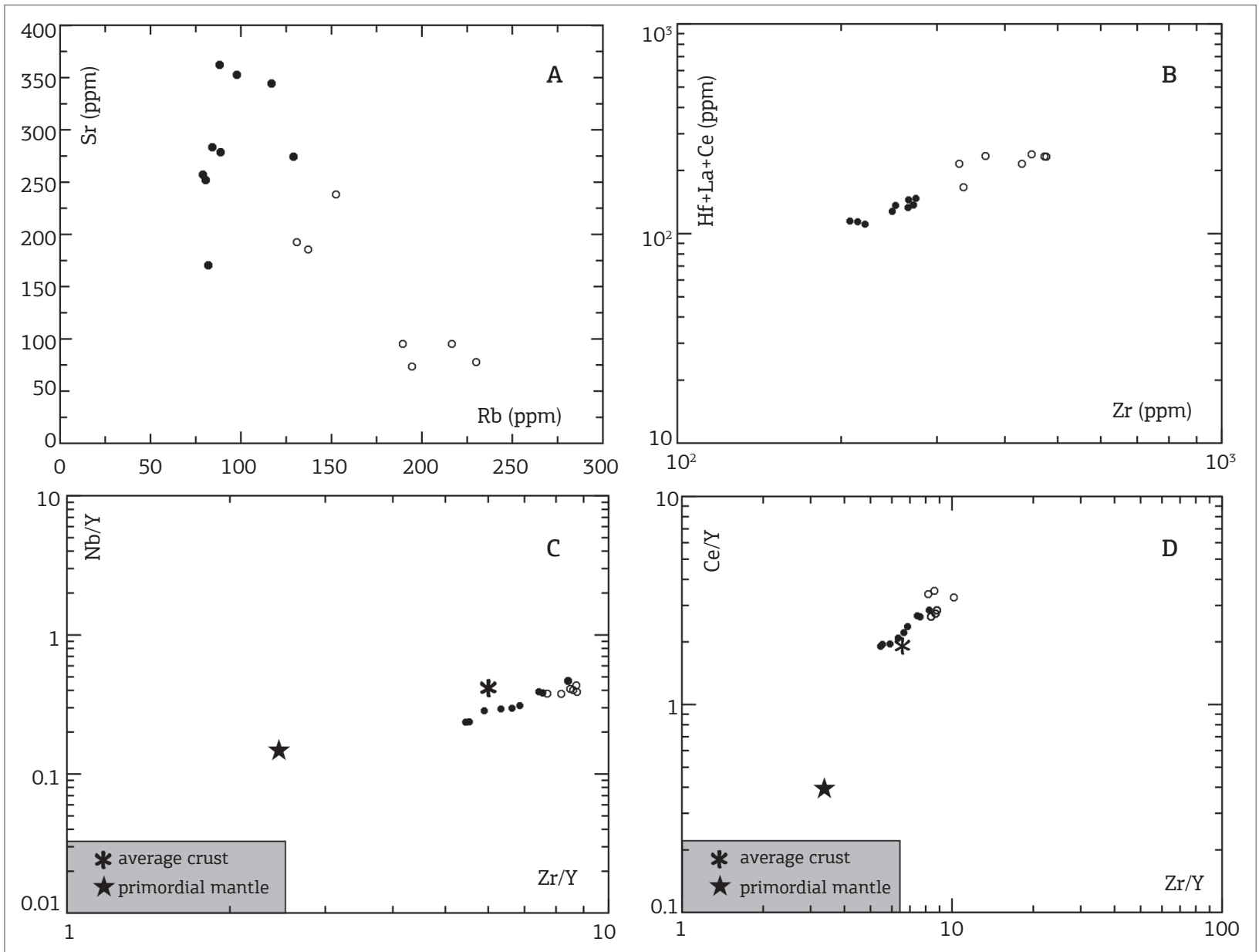

Figure 8. $\mathrm{Rb}$ versus $\mathrm{Sr}(\mathrm{A}), \mathrm{Zr}$ versus $\mathrm{Hf}+\mathrm{La}+\mathrm{Ce}(\mathrm{B}), \mathrm{Zr} / \mathrm{Y}$ versus $\mathrm{Nb} / \mathrm{Y}(\mathrm{C})$ and $\mathrm{Zr} / \mathrm{Y}$ versus $\mathrm{Ce} / \mathrm{Y}$ (D) ratios plots for acidic and intermediary rocks from Iricoumé Group. Primordial mantle of Wood et al. (1979) and average continental crust of Rudnick \& Fountain (1995) (blank circle = acid rocks and filled circle = intermediate rocks). 


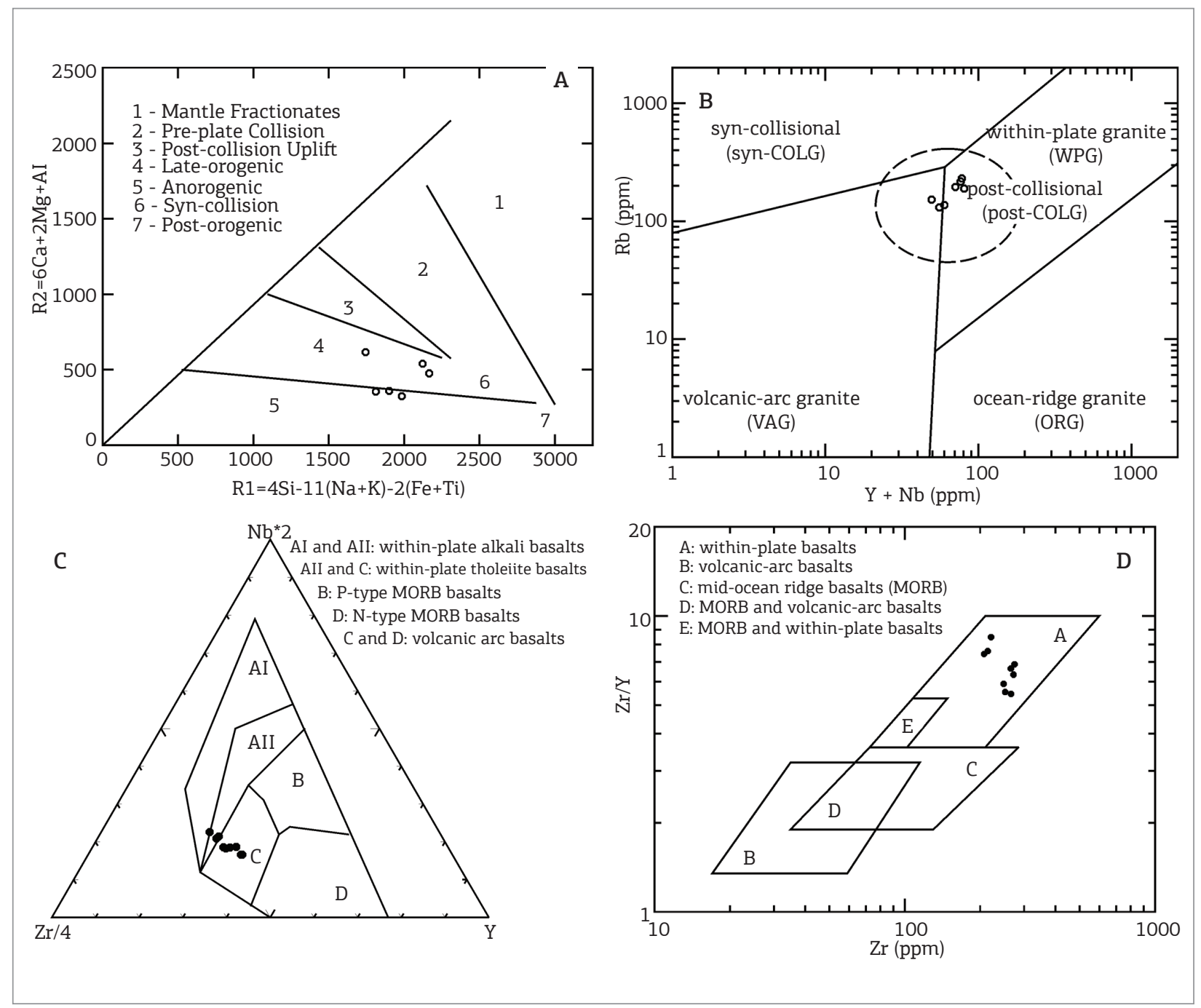

Figure 9. Tectonic discriminant diagrams for the Iricoumé Group rocks (blank circle = acid rocks and filled circle = intermediate rocks). (A) Multicationic R1 versus R2 diagram for acid rocks (Batchelor \& Bowden 1985); (B) Rb versus $\mathrm{Y}+\mathrm{Nb}$ diagram for acid rocks (Pearce 1996); (C) Nb*2 versus $\mathrm{Zr} / 4$ versus $\mathrm{Y}$ triangular diagram for basaltic rocks (Meschede 1986); (D) Z versus Zr/Y diagram for basaltic rocks (Pearce \& Norry 1979).

material (Souza et al. 2007). On the basis of the study by Bryan (2007) and Bryan \& Ernst (2008) proposals, discussed by Klein et al. (2012), the high magma volume produced at a short time registered in this region is compatible with Silicic Large Igneous Province (SLIP).

\section{CONCLUSIONS}

The Iricoumé volcanism in the southernmost Guyana shield consists of a bimodal association comprising andesite/basalt to rhyolite components. The acid rocks are subalkaline with high-K, metaluminous-to-peraluminous compositions, geochemically compatible to A-type magmatism emplaced in post-collisional to within-plate tectonic settings. The intermediate rocks are subalkaline with medium- to high- $\mathrm{K}$ contents, metaluminous nature and geochemically compared with within-plate and post-collisional uplift toleiitic basalts.

The $\mathrm{U}-\mathrm{Pb}$ age presented here for the rhyolites (1882 \pm $11 \mathrm{Ma}$ ) is consistent with the $\mathrm{Pb}-\mathrm{Pb}$ age already reported for the Iricoumé volcanic rocks in this region. The $\mathrm{T}_{\mathrm{DM}}$ model ages $(2.59-2.16 \mathrm{Ga})$ and $\varepsilon_{\mathrm{Nd}}(t)(-5.43-0.03)$ indicate that the magmatic evolution was preferentially related to reworking of older Paleoproterozoic 
(Rhyacian or Siderian) juvenile continental crust with some contribution from mantle-derived basaltic magmas. It is also possible that there was some contamination by Archean crust.

The data presented here supports the within-plate or post-collisional tectonic setting proposed for the Iricoumé volcanism, most likely to crustal uplift and melting promoted by the emplacement of basalt magma in an extensional regime. This extensive volcanic event was associated with caldera system complex with the eventual collapse and magma resurgence during a short-time interval, comparable to other SLIP in other parts of the world.

\section{ACKNOWLEDGEMENTS}

This research was financially supported by Brazilian National Council of Technological and Scientific Development (CNPq), CT-Amazonian project (MCTCNPq No. 575520/2008-6). We thank CNPq for the scholarship granted to the first author, as well as the technical staff of the isotope geology laboratories at the Universidade de Brasília for their help. The authors are grateful to Dr. Farid Chemale Jr. (IG-UnB) for assistance in processing of the isotope geology data. Finally, we thank Dr. Márcio M. Pimentel (IG-UnB) for the review and critique applied to the manuscript.

\section{REFERENCES}

Almeida M.E. 2006. Evolução Geológica da porção centrosul do escudo das Guianas com base no estudo geoquímico, geocronológico (evaporação de $\mathrm{Pb}$ e U-Pb ID-TIMS em zircão) e isotópico $(\mathrm{Nd}-\mathrm{Pb})$ dos granitóides Paleoproterozóicos do sudeste de Roraima. Tese de Doutorado, Universidade Federal do Pará, Instituto de Geociências, Belém, p. 227.

Almeida M.E., Macambira M.J.B., Oliveira E.C. 2007. Geochemistry and zircon geochronology of the I-type high-K calc-alkaline and S-type granitoid rocks from southeastern Roraima, Brazil: Orosirian collisional magmatism evidence (1.97-1.96 ga) in central portion of Guyana shield. Precambrian Research, 155:69-97.

Almeida M.E. \& Macambira M.J.B. 2007. Geology and petrography of paleoproterozoic granitoid rocks from Uatumã-Anauá Domain, central region of Guyana shield, southeastern Roraima, Brazil. Revista Brasileira de Geociências, 37(1):237-256.

Andrews G.D.M. \& Branney M.J. 2011. Emplacement and rheomorphic deformation of a large, lava-like rhyolitic ignimbrite: Grey's Landing, southern Idaho. Geological Society of American Bulletin, 123(3/4):725-743.

Araújo Neto H. \& Moreira H.L. 1976. Projeto Estanho de Abonari, vol. 1. MME/DNPM/CPRM, Brasília, p. 232

Barreto C.J.S., Lafon J.M., Costa L.T.R., Magalhâes, L.B. 2012. Geoquímica, geocronologia $\mathrm{Pb}-\mathrm{Pb}$ em zircão e Sm-Nd em rocha total do vulcanismo félsico Orosiriano do Grupo iricoumé, Província Amazônbia Central, sul do Escudo das Guianas. In: Congresso Brasileiro de Geologia, 46º, SBG, Santos, CD-ROM.

Barreto C.J.S., Lafon J.M., Costa L.T.R., Lima E.F. 2013. Vulcanismo félsico paleoproterozoico do Grupo Iricoumé, Domínio ErepecuruTrombetas, Província Amazônia Central: dados de campo, caracterização petrográfica e geocronologia $\mathrm{Pb}-\mathrm{Pb}$ em zircão. Revista do Instituto de Geociências da USP, São Paulo. 13(1):47-72.

Batchelor A.R. \& Bowden P. 1985. Petrogenetic interpretation of granitoid rock series using multicationic parameters. Chemical Geology, 48:43-55.

Bonin B. 2007. A-type granites and related rocks: evolution of a concept, problems and prospects. Lithos, 97(1-2):1-29.

Boynton W.V 1984. Cosmogeochemistry of the rare earth elements: meteorite studies. In: Henderson P. (ed.), Rare Earth Element Geochemistry. Elsevier, p. 63-114.
Bryan S.E. 2007. Silicic large igneous provinces. Episodes, 30:20-31.

Bryan S.E. \& Ernst R.E. 2008. Revised definition of Large Igneous Provinces (LIPs). Earth-Science Reviews, 86(1-4):175-202.

Bühn B., Pimentel M.M., Matteini M., Dantas E.L. 2009 High spatial resolution analysis of $\mathrm{Pb}$ and $\mathrm{U}$ isotopes for geochronology by laser ablation multi-collector inductively coupled plasma mass spectrometry (LA-MC-ICP-MS). Anais da Academia Brasileira de Ciências. 81:1-16.

Clemens J.D., Holloway J.R., White A.J.R. 1986. Origin of an A-type granite: experimental constraints. American Mineralogist, 71:317-324.

Collins W.J., Beams S.D., White A.J.R., Chappell B.W. 1982. Nature and origin of A-type granites. Contributions to Mineralogy and Petrology, 80:189-200

Costa C.F.M. 2010. Evolução geológica da região de Pitinga (Amazonas) e suas implicações na gênese da mineralização de $\mathrm{Sn}-\mathrm{Nb}-\mathrm{Ta}-\mathrm{F}(\mathrm{Y}, \mathrm{ETR}, \mathrm{Li}$ ) associada ao granito Madeira. Tese de Doutorado, Instituto de Geociências, Universidade Federal do Rio Grande do Sul, Porto Alegre, p. 126.

Costi H.T., Dall'Agnol R., Moura C.A.V. 2000. Geology and Pb-Pb geochronology of Paleoproterozoic volcanic and granitic rocks of the Pitinga Province, northern Brazil. International Geology Reviews, 42:832-849.

Costi H.T., Borges R.M.K., Dall'Agnol R. 2005. Depósitos de estanho da Mina Pitinga, Estado do Amazonas. In: Marini O.J., Queiroz E.T., Ramos, B.W. (eds.), Caracterização de Depósitos Minerais em Distritos Mineiros da Amazônia. DNPM-CTMineral/FINEP-ADIMB, Brasília, cap. VII, p. 391-475

CPRM. 2006. Geologia e recursos minerais do Estado do Amazonas. MME/CPRM/CIAMA, Programa de Geologia do Brasil (mapas geológicos estaduais, escala 1:1.000.000), Manaus, Texto Explicativo, p. 144, CR-ROM.

CPRM. 2008. Geologia e recursos minerais do Estado do Pará. MME/CPRM, Programa de Geologia do Brasil (mapas geológicos estaduais, escala 1:1.000.000), Belém, Texto Explicativo, p. 288, CR-ROM. 
Creaser R.A., Price R.C., Wormald R.J. 1991. A-type granites revisited: assessment of a residual source model. Geology, 19:163-166

Cunha P.R.C., Gonzaga F.G., Coutinho L.F.C., Feijó F.J. 1994. Bacia do Amazonas. Boletim de Geociências da Petrobras, 1:47-55.

Dall'Agnol R., Lafon J.M., Macambira M.J.B. 1994. Proterozoic anorogenic magmatism in the Central Amazonian Province, Amazonian Craton: geochronological, petrological and geochemical aspect. Mineralogy and Petrology, 50(1/3):113-138.

Davies J.H. \& Blanckenburg F. 1995. Slab breakoff: a model of lithosphere detachment and its test in the magmatism and deformation of collisional orogens. Earth and Planetary Science Letters, 129:85-102.

De Paolo D. 1981. Neodymium isotopes in the Colorado Front Range and crust-mantle evolution in the Proterozoic. Nature, 291:193-196.

Eby G.N. 1992. Chemical subdivisions of A-type granitoids: petrogenesis and tectonic implications. Geology, 20:614-644.

Elkins-Tanton L.T. 2005. Continental mechanism caused by lithosphere delamination. Geological Society of America Special Paper, 388:449-461.

Fernandes C.M.D., Lamarão C.N., Teixeira N.P. 2006. Vulcanismo bimodal do tipo Uatumã da região de São Feliz do Xingu (PA), Província Mineral de Carajás. Revista Brasileira de Geociências, 36(3):565-576.

Ferron J.M.T.M., Bastos Neto A.C., Rolim S.B.A., Hoff R., Umann L.V., Minuzzi O.R.R. 2002. Reconhecimento de uma megaestrutura no Distrito Mineiro de Pitinga-AM: dados preliminaresa a partir da aplicação de técnicas de processamento digital de imagens ETM+Land-sat 7. In: Atas do Simpósio de Vulcanismo e Ambientes Associados, 2º, SBG-NO, Belém, CD-ROM.

Ferron J.M.T.M. 2006. Geologia regional, geoquímica e geocronologia $\mathrm{Pb}-\mathrm{Pb}$ de rochas graníticas e vulcânicas paleoproterozóicas da Província Pitinga, cráton Amazônico. Tese de Doutoramento, Instituto de Geociências, Universidade Federal do Rio Grande do Sul, p. 331

Ferron J.M.T.M., Bastos Neto A.C., Lima E.F., Costi H.T., Moura C.A.V., Prado M., Pierosan R., Galarza M.A. 2006. Geologia e geocronologia $\mathrm{Pb}-\mathrm{Pb}$ de rochas graníticas e vulcânicas ácidas a intermediárias paleoproterozóicas da província Pitinga, craton Amazônico. Revista Brasileira de Geociências, 36(3):499-512.

Ferron J.M.T.M., Bastos Neto A.C., Lima E.F., Nardi L.V.S., Costi H.T., Pierosan R., Prado M. 2010. Petrology, geochemistry, and geochronology of Paleoproterozoic volcanic and granitic rocks (1.89-1.88 Ga) of the Pitinga Province, Amazonian Craton, Brazil. Journal of South American Earth Sciences, 29:483-497.

Fuck R.A., Pimentel M.M., Machado N., Daoud W.E.K. 1993. Idade $\mathrm{U}-\mathrm{Pb}$ do Granito Madeira, Pitinga (AM). In: Anais do Congresso Brasileiro de Geoquímica, 4º Brasília, Resumos expandidos, p. 246-249.

Gioia S.M.L. \& Pimentel M.M. 2000. The Sm-Nd isotopic method in the Geochronology Laboratory of the University of Brasília. Anais da Academia Brasileira de Ciências, 72(2):219-245.

Goldstein S.L., O’Nions R.K., Hamilton P.J. 1984. A Sm-Nd isotopic study of atmospheric dusts and particulates form major river systems. Earth and Planetary Science Letters, 70:221-236.

Haggerty S.E. 1991. Oxide textures - a mini-atlas. In: Lindsley D.H. (ed.), Oxide Minerals: Petrologic and Magnetic Significance, vol. 25, Reviews in Mineralogy, Mineralogical Society of America, p. 129-219.
Horbe M.A., Horbe A.M.C. Costi H.T., Teixeira J.T. 1991. Geochemical characteristics of cryolite-tin-bearing granites from the Pitinga mine. Journal Geochemical Exploration, 40:227-249

Horbe A.M.C., Nogueira A.C.R., Horbe M.A., Costa M.L., Suguio K. 2001. A lateritização da gênese das superfícies de aplainamento da região de Presidente Figueiredo Balbina, nordeste do Amazonas. In: Reis N.J. \& Monteiro M.A.S (coord.), Contribuições à Geologia da Amazônia, Manaus, 2º, SBG-NO, p. 145-176.

Juliani C. \& Fernandes C.M.D. 2010. Well-preserved Late Paleoproterozoic volcanic centers in the São Félix do Xingu region, Amazonian Craton, Brazil. Journal of Volcanology and Geothermal Research, 191:167-179.

Klein E., Almeida M.E., Rosa-Costa L.T. 2012. The 1.89-1.87 Ga Uatumã Silicic Large Igneous Province, northern South America. In: International Association of Volcanology and Chemistry of the Earth's Interior, Large Igneous Province Commission, November 2012 LIP of the month (http://www. largeigneousprovinces.org)

Le Maitre R.W., Bateman P., Dudek A., Keller J., Lemeyre J., Le Bassabine P.A., Schimid R., Sorensen H., Streckeisen A., Wooley A.R., Zanettin B. 1989. A Classification of Igneous Rocks and Glossary of Terms. Blackwell, Oxford, p. 193.

Lenharo S.L., 1998. Evolução magmática e modelo metalogenético dos granitos mineralizados da região de Pitinga. Amazonas, Brasil. Tese de Doutorado, Escola Politécnica, Universidade de São Paulo (USP), São Paulo, p. 290.

Ludwig K.R. 2003. User's Manual for Isoplot/Ex, Version 3.0, a geochronological toolkit for Microsoft Excel Berkeley Geochronology Center. In: Special Publication, vol. 4, Berkeley, Geochronology Center, 2455 Ridge Road, Berkeley, CA 94709, USA.

Macambira M.J.B., Almeida M.E., Santos L.J. 2002. Idade de zircão de vulcânicas Iricoumé do sudeste de Roraima: contribuição para a redefinição do Supergrupo Uatumã. In: Simpósio sobre Vulcanismo e Ambientes Associados, $2^{\circ}$, Boletim de Resumos e Guia de Excursão, UFPACG/SBG-NO, Belém, p. 22

Maniar P.D. \& Piccoli P.M. 1989. Tectonic discrimination of granitoids. Geological Society of America Bulletin, 101:635-643.

Marques S.N.S., Nascimento R.S.C., Souza V.S., Dantas E.L. 2007. Características geoquímicas das rochas vulcânicas do Grupo Iricoumé, em perfis estratigráficos, na região de Presidente Figueiredo-AM. In: Anais do Simpósio de Geologia da Amazônia, 10², SBG-NO, Porto Velho, CD-ROM.

Marques S.N.S. 2011. Geologia, geoquímica e geocronologia SMNd de rochas vulcânicas do Grupo Iricoumé, sul do Escudo das Guianas, Presidente Figueiredo (AM). Dissertação de Mestrado, Programa de Pós-Graduação em Geociências, Universidade Federal do Amazonas, Manaus, p. 73.

Meschede M. 1986. A method of discriminating between different types of mid-ocean ridge basalts and continental tholeiites with the Nb-Zr-Y diagram. Chemical Geology, 56:207-218

Nogueira A.C.R. 1999. Depósitos costeiros neoproterozóicos da Formação Prosperança, Município de presidente Figueiredo, Estado do Amazonas. In: Anais do Simpósio de Geologia da Amazônia, Manaus, 6º, SBG-NO, Manaus, p. 412-415.

Oliveira A.S., Fernandes C.A.C., Issler R.S., Montalvão R.M.G., Teixeira W. 1975. Geologia da Folha NA.21-Tumucumaque e parte da Folha NB.21. BRASIL, vol. 9. DNPM, Projeto RADAMBRASIL, Levantamento de Recursos Minerais, Rio de Janeiro, p. 21-118. 
Pearce J. 1996. Sources and settings of granitic rocks. Episodes, 19(4):120-125.

Pearce J. \& Norry M.J. 1979. Petrogenetic implications of Ti, Zr, Y and $\mathrm{Nb}$ variations in volcanic rocks. Contributions to Mineralogy and Petrology, 69:33-47.

Pierosan R. 2009. Geologia, litogeoquímica e química mineral do Grupo Iricoumé e da Formação Quarenta Ilhas no Distrito Mineiro de Pitinga - AM - Brasil. Tese de Doutoramento, Instituto de Geociências, Universidade Federal do Rio Grande do Sul, Porto Alegre, p. 205.

Pierosan R., Lima E.F., Nardi L.V.S., Bastos Neto A.C., Campos C.P., Jarvis K., Ferron J.M.T.M., Prado M. 2011a. Geochemistry of Palaeoproterozoic volcanic rocks of the Iricoumé Group, Pitinga Mining District, Amazonian craton, Brazil. International Geology Review, 53:946-979.

Pierosan R., Lima E.F., Nardi L.V.S., Campos C.P., Bastos Neto A.C., Ferron J.M.T.M., Prado M. 2011b. Paleoproterozoic ( 1.88Ga) felsic volcanism of the Iricoumé Group in the Pitinga Mining District area, Amazonian craton, Brazil: insight in ancient volcanic process from field and petrologic data. Anais da Academia Brasileira de Ciências, 83(3):921-937.

Pinho M.A.S.B., Rubert R.R., Silva G.D., Chemale Jr. F., Dussin I.A., Costa E.C. 2004. Dados Petrográficos, Geoquímicos e idades U-Pb da vulcânica félsica do Grupo Iriri na porção nordeste de Mato Grosso - Serra dos Magalhães. In: Anais do Congresso Brasileiro de Geologia, 42 , Araxá, CD-ROM.

Pioli L. \& Rosi M. 2005. Rheomorphic structures in a highgrade ignimbrite: the Nuraxi tuff, Sulcis volcanic district (SW Sardinia, Italy). Journal of Volcanology and Geothermal Research, 142:11-28.

Pirajno F. 2007. Mantle dynamics, associated intraplate tectonomagmatic processes and ore systems. Episodes, 30:6-19.

Pirajno F. \& Hoatson D.M. 2012. A review of Australia's Large Igneous Provinces and associated mineral systems: implications for mantle dynamics through geological time. Ore Geology Reviews, 48: 2-54.

Reis N.J., Fraga L.M., Faria M.S.G., Almeida M.E. 2003. Geologia do Estado de Roraima. Géologie de La France, 2-3-4:121-134.

Rocha M.L.B.P., Barros M.A.S., Lima E.F., Pierosan R. 2012. Paleoproterozoic domo of lava from Iriri Group - Sonho Meu Farm - northeast of Mato Grosso, Amazon Craton: geology, geochemistry, and geochronology. Revista Brasileira de Geociências, 42(3):471-488.

Rollinson H., 1993. Using Geochemical Data: Evaluation, Presentation, Interpretation. Longman Scientific \& Technical, John Wiley \& Sons, New York, p. 352.

Rudnick R.L. \& Fountain D.M. 1995. Nature and composition of the continental crust: a lower crustal perspective. Reviews of Geophysics, 33:267-309.

Santos J.O.S., Hartmann L.A., Gaudette H.E., Groves D.I., Mcnaughton N.J., Fletcher I.R.A. 2000. A new understanding of the provinces of the Amazon Cráton based on integration of field mapping and $\mathrm{U}-\mathrm{Pb}$ and $\mathrm{Sm}-\mathrm{Nd}$ geochronology. Gondwana Research, 3(4):453-488

Santos J.O.S., Hartmann L.A., McNaugthon N.J., Fletcher I.R. 2002. Timing of mafic magmatism in the Tapajós Province (Brazil) and implications for the evolution of the Amazon Craton: evidence from baddeleyite and zircon U-Pb SHRIMP geochronology. Journal of South America Earth Science, 15:409-429.
Saunders A.D., Storey M., Kent R.W., Norry M.J. 1992. Consequences of plume-lithosphere interactions. In: Storey B.C., Alabaster T., Pankhurst R.J. (eds.), Magmatism and the Causes of Continental Break-up. Geological Society of London, Special Publication, n. 68, p. 41-60.

Schobbenhaus C., Hoppe A., Baumann A., Lork A. 1994. Idade $\mathrm{U}-\mathrm{Pb}$ do magmatisimo Uatumã no norte do Cráton Amazônic Escudo das Guianas (Brasil). In: Anais do Congresso Brasileiro de Geologia, vol. 2, 38 , Balneário de Camboriú, p. 397-399.

Souza V.S., Marques S.N.S., Nascimento R.S., Valério C.S. 2007. Texturas e estruturas em rochas piroclásticas e vulcânicas paleoproterozóicas do Grupo Iricoumé, sudeste do Município de Presidente Figueiredo (AM). In: Anais do Simpósio de Geologia da Amazônia, 10, SBG-NO, Porto Velho, CD-ROM.

Souza V.S. \& Nogueira A.C.R. 2009. Seção geológica ManausPresidente Figueiredo (AM), borda norte da Bacia do Amazonas: Um guia para excursão de campo. Revista Brasileira de Geociências, 39(1):16-19.

Tassinari C.C.G. \& Macambira M.J.B. 1999. Geochronological provinces of the Amazonian Craton. Episodes, 22(3):174-182.

Tassinari C.C.G., Bettencourt J.S., Geraldes M.C., Macambira M.J.B., Lafon J.M. 2000. The Amazonian Craton. In: Cordani U.G., Milani E.J., Thomaz Filho A., Campos D.A. (eds.), Tectonic Evolution of South America, 31st International Geological Congress, Rio de Janeiro, Brazil, p. 41-95.

Thompson R.N. 1982. Magmatism of the British Tertiary volcanic province. Scottish Journal of Geology, 18:49-107.

Turner S.P., Foden J.D., Morrison R.S. 1992. Derivation of some A-type magmas by fractionation of basaltic magma: an example from the Padthaway Ridge, South Australia. Lithos, 28:151-179.

Valério C.S. 2006. Magmatismo Paleoproterozóico do estremosul do Escudo das Guianas, município de Presidente Figueiredo (AM): geologia, geoquímica e geocronologia $\mathrm{Pb}-\mathrm{Pb}$ em zircão. Dissertação de Mestrado, Departamento de Geociências, Universidade Federal do Amazonas, Manaus, p. 112.

Valério C.S., Souza V.S., Macambira M.J.B., Galarza M.A. 2006. Geoquímica e geocronologia $\mathrm{Pb}-\mathrm{Pb}$ em zircão da Suíte Intrusiva Água Branca, Município de Presidente Figueiredo (AM): evidências de colisão no Paleoproterozóico da Amazônia Ocidental. Revista Brasileira de Geociências, 36(3):1-13.

Valério C.S., Souza V.S., Macambira M.J.B. 2009. The 1.90-1.88 Ga magmatism in the southernmost Guyana shield, Amazonas, Brazil: geology, geochemistry, zircon geochronology, and tectonic implications. Journal of South American Earth Sciences, 28:304-320

Valério C.S. 2011. Petrologia e tectônica de granitos Paleoproterozóicos das suítes Água Branca e Mapuera, sul do Domínio Uatumã-Anauá, NE do Amazonas. Tese de Doutorado, CPGG/CG, Universidade Federal do Pará, p. 123.

Valério C.S., Macambira M.J.B., Souza V.S. 2012. Field and petrographic data of 1.90-1.88 Ga I- and A-type granitoids from the central Amazonian Craton, NE Amazonas State, Brazil. Revista Brasileira de Geociências, 42(4):690-712.

Veiga Jr. J.P., Nunes A.C.B., Souza E.C., Santos J.O.S., Amaral J.E., Pessoa M.R., Souza S.A. 1979. Projeto Sulfetos de Uatumã, Manaus, DNPM/CPRM, Relatório Final, 6v

Whalen J.B., Currie K.L., Chappell B.W. 1987. A-type granites: geochemical characteristics, discrimination and petrogenesis. Contributions to Mineralogy and Petrology, 95:407-419. 
Whalen J.B., Jenner G.A., Longstaffe F.J., Robert F., Cariépy C. 1996. Geochemical and isotopic (O, Nd, Pb and Sr) constraints on A-type granite petrogenesis based on the Topsails Igneous Suite, Newfoundland Appalachians. Journal of Petrology, 37(6):1463-1489.

Winchester J.A. \& Floyd P.A. 1977. Geochemical discrimination of different magma series and their differentiation products using immobile elements. Chemical Geology, 20:325-343.
Wood D.A., Joron J.L., Treuil M., Norry M., Tarney J. 1979. Elemental and $\mathrm{Sr}$ isotope variations in basic lavas from Iceland and the surrounding ocean floor. Contributions to Mineralogy and Petrology, 70:319-339.

Arquivo digital disponível on-line no site www.sbgeo.org.br 